\title{
Role of Endophytes and Rhizosphere Microbes in Promoting the Invasion of Exotic Plants in Arid and Semi-Arid Areas: A Review
}

\author{
Elsiddig A. E. Elsheikh ${ }^{1,2, *}$, Ali El-Keblawy ${ }^{1}{ }^{(0}$, Kareem A. Mosa $\left.{ }^{1,3}{ }^{(}\right)$, Anthony I. Okoh ${ }^{4,5}$ and Ismail Saadoun ${ }^{1}$ \\ 1 Department of Applied Biology, College of Sciences, University of Sharjah, \\ Sharjah 27272, United Arab Emirates; akeblawy@sharjah.ac.ae (A.E.-K.); kmosa@sharjah.ac.ae (K.A.M.); \\ isaadoun@sharjah.ac.ae (I.S.) \\ 2 Department of Soil and Environment Sciences, Faculty of Agriculture, University of Khartoum, \\ Khartoum 11115, Sudan \\ 3 Department of Biotechnology, Faculty of Agriculture, Al-Azhar University, Cairo 11651, Egypt \\ 4 Department of Environmental Health Sciences, College of Health Sciences, University of Sharjah, \\ Sharjah 27272, United Arab Emirates; aokoh@sharjah.ac.ae \\ 5 SAMRC Microbial Water Quality Monitoring Centre, University of Fort Hare, Alice 5700, South Africa \\ * Correspondence: eelsheikh@sharjah.ac.ae
}

\section{check for} updates

Citation: Elsheikh, E.A.E.; El-Keblawy, A.; Mosa, K.A.; Okoh, A.I.; Saadoun, I. Role of Endophytes and Rhizosphere Microbes in Promoting the Invasion of Exotic Plants in Arid and Semi-Arid Areas: A Review. Sustainability 2021, 13, 13081. https://doi.org/10.3390/su132313081

Academic Editors: Daolin Du, Jian Li, Guanlin Li and Hui Jia

Received: 26 October 2021

Accepted: 17 November 2021

Published: 26 November 2021

Publisher's Note: MDPI stays neutral with regard to jurisdictional claims in published maps and institutional affiliations.

Copyright: (c) 2021 by the authors. Licensee MDPI, Basel, Switzerland. This article is an open access article distributed under the terms and conditions of the Creative Commons Attribution (CC BY) license (https:/ / creativecommons.org/licenses/by/ $4.0 /)$.

\begin{abstract}
Endophytes and rhizospheric microorganisms support invasive species' adaptation to environmental stresses. Here, we review the impacts of endophytes, rhizospheric microbes (particularly symbiotic nitrogen-fixers), mycorrhiza and pathogens on plant invasion in arid and semi-arid areas. Endophytes and soil microorganisms either enhance nutrient acquisition for enhancing the invasive plant immune system and/or negatively affect native plants. In addition, the positive feedback between mycorrhizal fungi and invasive plants enhances the competitive ability of the aliens, providing them more opportunities for success, establishment, and dominance. The microbes and their secondary metabolites promote invasive plant species by changing soil microbial community structure and carbon biomass as well as enzyme activity, which improves soil properties and processes. The negative impact of invasive exotic plants on the associated biota and the role of allelochemicals are also discussed. It could be concluded that endophytes interact with rhizosphere microbes to promote invasive plant species in arid and semi-arid areas in a way similar to what happens in other ecosystems; the differences are in the pathways and reactions, which depend upon the prevailing abiotic factors. More interdisciplinary field experiments integrating microbial, biotechnological, and molecular approaches are needed to understand the role of symbiotic microbes in invasion biology.
\end{abstract}

Keywords: allelochemicals; arid lands; endophytes; ecological impacts; invasive plants; mycorrhiza; rhizosphere; Rhizobium; soil microorganisms

\section{Introduction}

High temperature and low rainfall are among the environmental stresses in arid lands, which occupy about one-third of the Earth's surface [1]. High temperatures coupled with low rainfall increase the water evaporation rate, which usually leads to soil salinization in arid lands [2]. Consequently, the high levels of toxic ions $\left(\mathrm{Na}^{+}\right.$and $\left.\mathrm{Cl}^{-}\right)$hinder nutrient absorption and affect ion homeostasis, which upsets cell growth and associated metabolic activities, affecting pigment synthesis and reducing photosynthesis [3,4]. Additionally, rapidly growing international trade has significantly enhanced the introduction of many exotic plants into different parts of the world [5]. Although the introduction of some alien plants was accidental, it was intentional for many others for wildlife habitat improvement, greening landscapes, wood or fiber production, soil conservation, livestock forage production, or other crop uses [6-9]. Many of the exotic plants have become invaders in the new areas. For example, in the arid environment of the UAE, the invasive Prosopis juliflora has 
been introduced for the afforestation and greening of the desert lands, but has escaped the forests and threatened the plant community of different ecosystems [10,11]. It is believed that the invasion of exotic plants is a major component of global change [12]. In addition, exotic plants are considered a major threat to the integrity and function of ecosystems and human health [13-17]. For example, invasive plants have potentially changed the ecosystems' geomorphology, hydrological cycles and biogeochemical properties [18-20].

Several invasive exotic plants have caused serious impacts on the associated biota in different parts of the world [21,22]. Invasive plants can change the composition and the diversity of the aboveground plant community structure $[23,24]$ and the belowground soil microbial community of the invaded ranges [25]. Despite most of their harmful effects, some exotic plants have benefited the environment and the associated biota in the introduced range [26]. For example, the growth of invasive nitrogen-fixing leguminous plants can improve soil physical and chemical properties, which might positively affect the associated species. Moreover, the canopies of Prosopis juliflora improved soil physical and chemical properties by increasing the important macro-nutrients, such as $\mathrm{K}, \mathrm{N}$ and $\mathrm{P}$, as well as the organic matter contents [7]. Similar benefits were reported for Acacia mangium on the environment and associated flora [26]. As negative and beneficial impacts of exotic plants on native communities do not act in isolation of each other in nature, the relative importance of each impact type determines the community structure of a certain environment [27].

In addition to their major role in ecosystem functions [28], soil and rhizospheric microorganisms play important roles in plant adaptation to environmental stresses. Among the important soil microbes that help plants' adaptation to environmental stresses are plant growth-promoting (PGP) microbes, nitrogen-fixing microorganisms, and mycorrhizal fungi [29]. PGP microbes regulate the levels of important stresses-tolerance hormones, e.g., abscisic acid and ethylene, and growth promotion hormones, e.g., auxin, gibberellin (GA), cytokinins (CKs), brassinosteroids (BRs), and strigolactones (SLs) [30,31]. Generally, soil microbial communities have an important role in the success of invasive exotic plant species in their new range [32]. Moreover, soil biota can facilitate or limit the invasion of exotic plants in the new ranges [33]. It was suggested that encountering fewer soil-borne enemies could facilitate the invasion, but encountering fewer beneficial microbes limits the invasive ability of exotic plants [11]. In addition, other invasive plants might encounter novel but strong soil mutualisms, which enhance their invasive success [33,34].

Endophytes, which are special groups of bacteria and fungi surviving within tissues of a host plant, can form different kinds of relationships with the host. These relationships range from latent pathogens or saprotrophs to mutualistic associations [35]. Endophytes interact and cooperate with other microbes colonizing plant tissues, e.g., mycorrhizal fungi, pathogens, and saprotrophs, to produce useful secondary metabolites that affect plant growth and plant responses to other biotic (e.g., pathogens) and abiotic stresses [36]. Several invasive plants adopt pathogenic endophytes to protect them from several kinds of diseases [37]. Importantly, a pathogenic endophyte does not cause a disease or damage its host plant, but can do so for other native flora [38]. It has been reported that plants hosting pathogenic endophytes could more effectively protected from some of the dangerous pathogens than plants free from such endophytes [39]. For example, pathogenic endophytes hosted by Dioscorea zingiberensis did not cause any damage to this plant, but their secondary metabolites protected it against other pathogens [38].

The role of microbes in the invasion process and the mitigation of stresses in invasive plants is well explored in many climatic zones around the world [40-48]. However, few studies have assessed the role of soil microbes and endophytes in the invasion process in arid lands $[37,49,50]$. Therefore, this review aimed to explore and discuss the role of endophytes, rhizospheric symbiotic nitrogen-fixing organisms, mycorrhiza and pathogens, and their interactions with invasive plants, in arid and semi-arid areas. 


\section{Role of Microorganisms and Endophytes at All Life Cycle Stages of Invasive Plant}

At all life cycle stages of the invasive plants in an arid ecosystem, endophytes and rhizospheric microorganisms together with root exudates and allelochemicals act in favor of invasion. The possible interactions of endophytes and rhizospheric microorganisms in facilitating the invasion of exotic plants in arid and semi-arid areas are shown in Figure 1. At the seedling stage, endophytes and allelochemicals improve seed germination and promote seedling growth. During earlier stages, the roots initiate symbiotic relationships with native mycorrhiza, nitrogen-fixing organisms, and other PGP microbes during plant growth Meanwhile, the allelochemicals produced by invasive plants promote their growth but suppress some pathogens and native plants. At maturity, the different types of beneficial microorganisms, such as mycorrhiza, nitrogen-fixing organisms, and PGP microbes, form a network in the rhizosphere area, protecting against pathogens and diseases and suppressing native flora; they alter the belowground biodiversity of the ecosystem and consequently improve their competitiveness and antagonistic synergic effects over the native plants. All these mechanisms are affected by the prevailing abiotic factors in arid and semiarid environments.

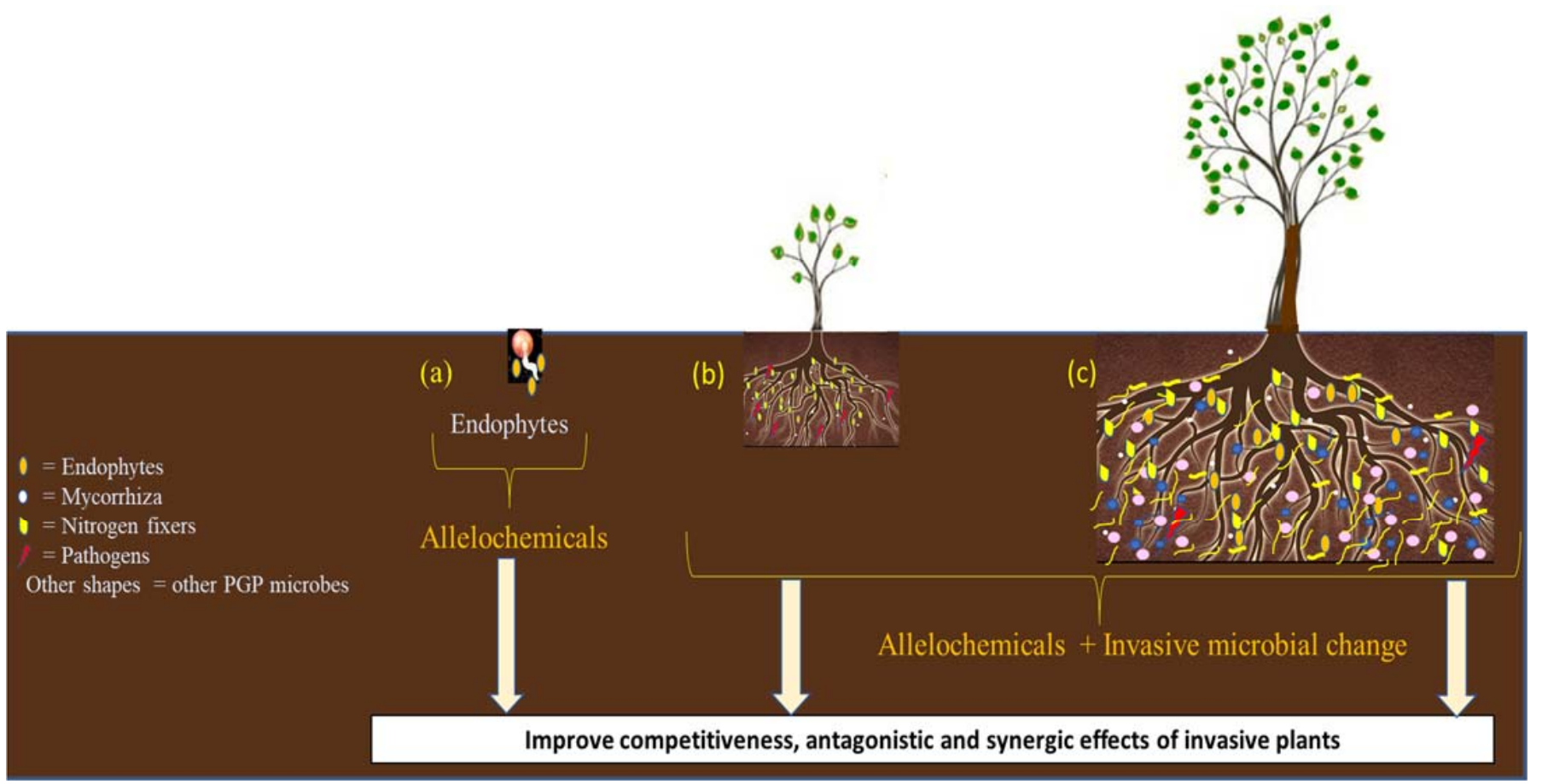

Figure 1. The possible interactions of endophytes and rhizospheric microorganisms in facilitating the invasion of exotic plants in arid and semi-arid areas. (a) Seedling stage, (b) vegetative and growth stage, (c) mature plant (for details see the text).

\section{Endophytes: Are They Tools That Promote Plants' Invasion?}

In arid and semi-arid environments, invasive and native plants harbor in their leaves, stems and roots large numbers and diverse communities of endophytic microorganisms [36,51-55]. Endophytes establish various types of symbiotic and mutualistic interactions with their host plant. They have an important ecological role in challenging arid environments [56]. Notably, some endophytes can facilitate plant invasion success [57,58]. Several reports presented the diversity of endophytes in various plant groups in arid lands. For example, Kulkarni and Nautiyal (1999) [59] isolated 44 fungal endophytes with significant antibacterial activity from the leaves of invasive Prosopis juliflora. Moreover, González-Menéndez et al., (2018) [55] isolated 349 fungal endophytes from leaves and stems of 63 invasive plant species; some of these isolates have high antifungal activities. In addition, Ratnaweera et al., (2015) [60] extracted equisetin, a compound with high 
antimicrobial activities, from endophytic Fusarium sp. isolated from the arid zone invasive Opuntia dilleniid. Invasive plants hosting antimicrobial endophytes are rarely harmed by these endophytes [36]. Interestingly, antimicrobial endophytes in an invasive host plant rarely cause a disease or harm the host, but can cause disease or damage for the associated native flora [38]. The possible roles of endophytes that favor the invasive plant species over native plant species in arid and semi-arid areas include: (i) ability to change microbial communities; (ii) influence microbial biomass carbon and enzymatic activity; (iii) change soil properties and processes and (iv) alter the aboveground vegetation (Table 1).

Table 1. Roles of endophytes in promoting invasive plant species in favor of native species in arid and semi-arid areas.

\begin{tabular}{|c|c|c|}
\hline Roles of Endophytes & Invasive Plant & Reference \\
\hline \multicolumn{3}{|l|}{ (i) Change microbial communities } \\
\hline $\begin{array}{l}\text { (a) Invasive species harbor more diversified bacterial communities compared } \\
\text { to the bulk soil }\end{array}$ & $\begin{array}{c}\text { Prosopis juliflora } \\
\text { Parthenium hysterophorus } \\
\text { Acacia longifolia } \\
\text { Prosopis juliflora }\end{array}$ & {$[61,62]$} \\
\hline (b) Alter the diversity and structure of native soil microbes in the rhizosphere & $\begin{array}{c}\text { Kalanchoe daigremontiana } \\
\text { Pennisetum setaceum } \\
\text { Schinus terebinthifolius }\end{array}$ & {$[47,63-67]$} \\
\hline (c) Increase the population of diazotrophs and total heterotrophs & Prosopis juliflora & [68] \\
\hline $\begin{array}{l}\text { (d) Modify and disturb the composition and structure of the mycorrhizal } \\
\text { community in the rhizosphere }\end{array}$ & $\begin{array}{l}\text { Acacia dealbata } \\
\text { Bromus tectorum }\end{array}$ & {$[69-71]$} \\
\hline (e) Encourage mycorrhizal association with invasive plant & Prosopis juliflora & [65] \\
\hline
\end{tabular}

(ii) Influence microbial biomass carbon and enzymatic activity

(a) Increase the microbial biomass of carbon

(b) Improve metabolic activity in the rhizosphere of invasive plant

(c) Influence and modify the enzyme activity

(d) Increase urease and glucosaminidase activities

\section{P. juliflora}

P. juliflora

Pennisetum setaceum

Prosopis juliflora

Acacia dealbata

Kalanchoe daigremontiana
[65]

[64]

$[47,64,65,69]$

[66]

\section{(a) Change soil processes}

(b) Influence the properties and processes of soils, increase nutrient availability

(c) Increase soil N, C and organic matter under invasive species

(d) Increase the salinity level in their rhizosphere of invasive species
Acacia longifolia

Kalanchoe daigremontiana

Prosopis juliflora

Acacia dealbata

Prosopis juliflora

Acacia dealbata

Atriplex sp.

Tamarix sp.
[72]

[64-66,69]

$[64,65,69]$

[1] (a) Improve alien plant growth

(b) Alter the aboveground vegetation

(c) Prohibit the establishment and growth of native species
Prosopis chilensis

Acacia longifolia

Prosopis juliflora

Kalanchoe daigremontiana

Acacia dealbata

Bromus tectorum
[54]

[62-66]

[69-71]

Invasive plants in arid and semi-arid regions are most likely to harbor more tolerant and effective strains than native plants. They have different mechanisms for the mitigation of biotic and abiotic stresses in many introduced or invaded areas. It seems that, in their strategy to tolerate biotic and abiotic stresses, invasive plants harbor a large number of endophytic strains that produce diverse compounds. For example, Srivastava and Anandrao (2015) [73] isolated a total of 446 fungal strains from the leaves of the invasive Prosopis juliflora. All these strains have different ways to assist the tree in withstanding and tolerating harsh environments, such as drought, salinity, diseases, and heavy metal toxicity. Endophytes in a specific plant or its rhizosphere, irrespective of their type, seem 
to coordinate their activities and functions in the host plant as an adaptive response to overcome biotic and abiotic stresses [74]. It is worth mentioning that all these strategies vary depending upon other abiotic factors, such as precipitation [75], drought and salinity [76], in addition to the effect of the soil microbial communities and extracellular enzymes in many terrestrial ecosystem processes.

Endophytes produce a wide range of secondary metabolites, which play direct or indirect roles in encouraging plant invasion. Among the roles of the secondary metabolites in invasive plants are: (i) regulation of antioxidant enzymes, such as ascorbic peroxidase, catalase, glutathione, superoxide dismutase, peroxidase, and polyphenol oxidase [77]; (ii) production of Jasmonic acid to defend the plant from biotic stress and damage [78]; (iii) production of salicylic acid, which causes systemic acquired resistance to mitigate pathogens, heat, salinity and drought stresses [79]; (iv) production of gibberellins to enhance plant growth and increase plant tolerance to stress [77]; (v) production of abscisic acid, which improves plant growth, promotes stomatal closure and mitigates stress damage [80] and (vi) improving plant resistance to pathogens [81,82].

However, the effects of secondary metabolites of endophytes varied greatly between invasive and native plants, and the endophytes of invasive species may be host-specific to facilitate plant invasion [83]. In general, invasive plants could benefit from association with endophytes to improve their competitiveness and sustain their invasiveness in two ways: (i) abundance of endophytes, such as mycorrhiza and PGP microbes, may improve plant growth, and the establishment and consequently the invasion of new areas $[84,85]$, and (ii) they use endophytes as novel weapons to produce novel allelopathic compounds to inhibit the native species $[60,86,87]$, and hence dominate in the new plant community. More explanations and examples are presented in Figure 2.

\begin{tabular}{|c|c|c|c|c|}
\hline & \multicolumn{2}{|c|}{ Beneficial effects to invaders } & \multicolumn{2}{|c|}{ Harmful effects natives } \\
\hline & Direct & In direct & Direct & In direct \\
\hline & (A) Improve invader immunity & $\begin{array}{l}\text { (B) Attack pathogens found in } \\
\text { invaded areas }\end{array}$ & $\begin{array}{l}\text { (C) Act as a pathogen to native } \\
\text { plants }\end{array}$ & $\begin{array}{l}\text { (D) Alter microbial community } \\
\text { and encourage pathogens } \\
\text { that attack native plants }\end{array}$ \\
\hline Endophyte & Methylobacterium sp & Bacillus sp. & Fusarium semitectum & $\begin{array}{l}\text { Abundant microsporidia (fungi- } \\
\text { related obligate parasites) }\end{array}$ \\
\hline Invasive plant species & Acacia farnesiana & Prosopis Juliflora & Chromolaena odorata & Harmonia axyridis \\
\hline $\begin{array}{l}\text { Positive role of the } \\
\text { endophyte to invader } \\
\text { plant }\end{array}$ & $\begin{array}{l}\text { Improves the antioxidant defense } \\
\text { and energy balance }\end{array}$ & $\begin{array}{l}\text { Inhibits the growth of Fusarium } \\
\text { solani, Fusarium equiseti and } \\
\text { Fusarium oxysporim and } \\
\text { consequently protects the invader } \\
\text { plant. }\end{array}$ & $\begin{array}{l}\text { The rhizosphere of invasive } \\
\text { Chromolaena sp. accumulates high } \\
\text { numbers of the a soil borne } \\
\text { pathogen, Fusarium semitectum, } \\
\text { which attacks native plants. }\end{array}$ & $\begin{array}{l}\text { Accumulates and spreads high } \\
\text { numbers of soil borne pathogens } \\
\text { and may alter the composition of } \\
\text { microbial communities and } \\
\text { consequently intensify the net } \\
\text { negative feedback and impacts on } \\
\text { native plants and microbes. }\end{array}$ \\
\hline Reference & [88] & [89] & [90] & [91] \\
\hline
\end{tabular}

Figure 2. Examples of possible roles of endophytes that benefit the invader plant species, and harm native plant species in arid and semi-arid regions References are: [88] Alcántara-Martínez et al., 2018; [89] Abdelmoteleb et al., 2017; [90] Mangla et al., 2008; and [91] Vilcinskas 2015.

Dark septate endophytes, for example, are recognized as good and promising candidate fungi in enhancing drought [92,93] and salinity tolerances [94], and increase plant biomass and nutrient concentration in invasive plants in arid environments [51,95]. Moreover, Knapp et al., (2012) [37] demonstrated that invasive grassland species could form associations with their roots' endophytic fungi in the invaded areas. They concluded that plants of semi-arid areas share common dominant members of the dark septate endophytes fungal present in their community [37]. Furthermore, the dark septate endophytes' colonization percentage and spore abundance depended on soil properties, type of host, and climatic factors [92,96]. As an example of a climatic factor in most arid lands, the high temperature significantly improved the mutual relationship between dark septate endophytes and the invasive Cenchrus ciliaris [92]. Interestingly, some dark septate endophytes were 
reported to have melanized hyphae [97], which enable both partners to tolerate high heat and drought stresses [95].

\section{Mycorrhiza: Multipurpose Roles for Invasive Plants}

Mycorrhizas (endomycorrhiza and ectomycorrhiza) are known worldwide to establish symbiotic associations with vascular plants $[3,28,85,98]$, where both partners exchange nutrients $[99,100]$. Among all the microbial-plant associations, mycorrhizal fungi are the preferable association for terrestrial plants [44]. It has been estimated that about $80 \%$ of vascular plant species are associated with mycorrhizal fungi $[51,70,98]$. For invasive plants, association with mycorrhiza is an adaptive strategy, particularly in arid and semi-arid ecosystems, where both partners benefit and increase their tolerance to biotic and abiotic environmental stresses [28]. Positive feedback between mycorrhizal fungal and invasive plants can contribute to a better chance for competition and more opportunities for success, establishment, and dominance of invasive plants $[50,85]$.

In low-resource arid environments, invasive plants tend to form associations with rhizobia and mycorrhizal fungi to obtain enough $\mathrm{N}$ and $\mathrm{P}$ to survive, improve establishment, and tolerate adverse conditions [101,102]. Mycorrhizal symbioses, through extensive hyphal networks in soil, protect invasive plant communities against environmental stresses, pathogens, nutrient deficiency, salinity stress, drought, and soil disturbance $[93,98,100,103,104]$. Generally, the numerous advantages of mycorrhizal-plant symbiosis could be sub-grouped at the levels of (a) individual mycorrhizal-plant, (b) community, and (c) the ecosystem (Figure 3).

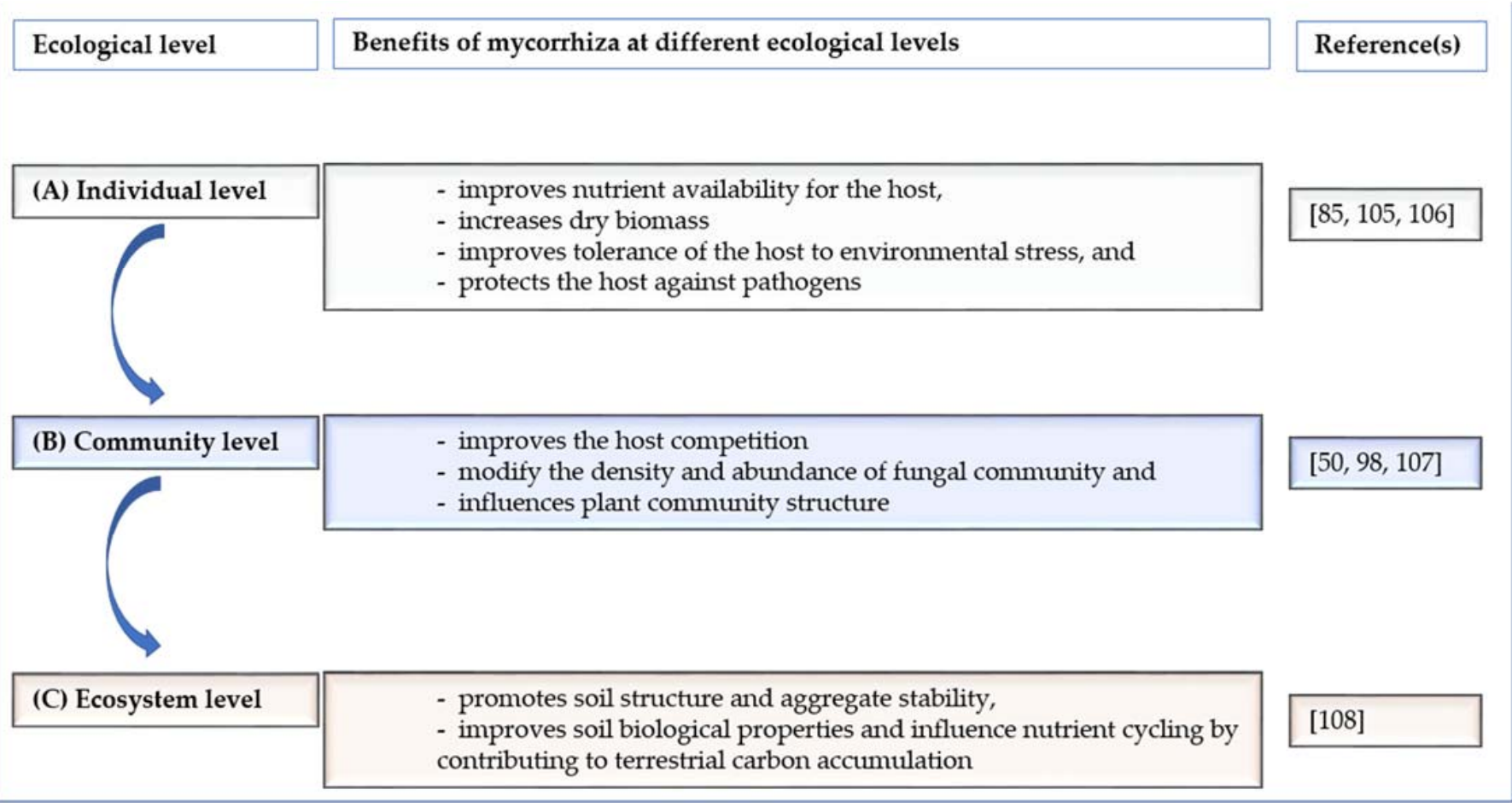

Figure 3. Benefits of mycorrhizal symbiosis in invasive plants at individual, community and ecosystem levels in arid and semi-arid environments. References are: [85] Aslani et al., 2019; [105] Makarov 2019; [106] Lumini et al., 2020; [50] de Souza et al., 2019; [98] Jung et al., 2012; [107] Zhao et al., 2019; [108] Mahmoudi et al., 2020.

In arid and semi-arid areas, different invasive plant species can develop mycorrhizal association as a means of invasion. According to Yanfang et al., (2012) [109] and Dhar et al., (2015) [110], mycorrhizal symbiosis could be adopted to enhance the invasion of some invasive plants, such as Asteraceae, in arid regions. Moreover, different shrub species in semi-arid environments harbor numerous and diverse types of mycorrhiza in their rhizosphere [111]. In general, different hypotheses have been proposed 
to explain mycorrhizal roles and mechanisms in supporting plant invasiveness: (a) Enhanced Mutualisms Hypothesis—favors the invader plant, [112]; (b) Degraded Mutualisms Hypothesis—negatively affects native plant [113]; and (c) Resistance Hypothesis—repels the invader plant [114].

According to Pringle et al., (2009) [115], many invasive plants can be associated with various types of endomycorrhizal or ectomycorrhizal species of fungi. Many reports $[50,71,116]$ analyzed and/or compared the effect of arbuscular mycorrhizal fungi communities and soil characteristics of invasive and native plants in arid and semi-arid areas. For example, de Souza et al., (2019) [50] found that invasive plants such as P. juliflora modify the density and abundance of the fungal community and consequently enhance its root colonization, increase dry biomass and plant phosphorous, and consequently support the growth and invasiveness over the native Mimosa tenuiflora. Moreover, mycorrhiza positively boosted the growth of invasive plants in drylands, increased plant dry weight, and improved mycorrhizal colonization [85,117]. Furthermore, under salt stress, inoculation of Acacia saligna with mycorrhiza in the presence of Rhizobium significantly improved plant nutrition, enhanced nodulation, and consequently improved plant growth and tolerance to salinity [118].

The efficiency of mycorrhizal association with invasive plants seems to depend upon the geographical region [115], environmental condition [84,101], nutrient availability [101], host specificity, genetics of the species [84,92] and resource availability [119]. Moreover, the colonization levels and spore abundance of mycorrhiza were correlated with edaphic, host specificity and climatic conditions [96]. In addition, Silva et al. (2014) [120] concluded that in Brazilian semi-arid regions, the mycorrhizal diversity is affected by vegetation, season, and soil type. As shown in Table 2, studies of mycorrhizal-invasive species in arid and semi-arid regions showed positive feedback favoring alien species over native plants.

Table 2. Major studies depicting the role of mycorrhiza in plant invasion in arid and semi-arid areas.

\begin{tabular}{|c|c|c|c|c|}
\hline Invasive Species & Growth Form & Invaded Habitat/Region & Main Findings & Reference(s) \\
\hline Cenchrus ciliaris & Grasses & $\begin{array}{l}\text { Sandy loam and alkaline } \\
\text { soil, Pakistan }\end{array}$ & $\begin{array}{l}\text { Mycorrhizal inoculation improved hyphal } \\
\text { colonization rate up to } 90 \%\end{array}$ & [92] \\
\hline Cenchrus ciliaris & Grasses & $\begin{array}{l}\text { pasture in semi-arid } \\
\text { regions, Brazil }\end{array}$ & $\begin{array}{l}31 \text { mycorrhizal species were detected mainly } \\
\text { from Acaulospora and Glomus }\end{array}$ & [121] \\
\hline Acacia farnesiana & Trees & Alkaline soils, India & $\begin{array}{c}\text { Spores of Acaulospora foveata, Gigaspora albida } \\
\text { and Glomus fasciculatum, G. geosporum and } \\
\text { Sclerocystis sinuosa were isolated }\end{array}$ & [96] \\
\hline Acacia saligna & Trees & Different areas, Ethiopia & $\begin{array}{l}\text { Highest species diversity of } 19 \text { species from } 7 \\
\text { genera compared to } 8 \text { Acacia spp. }\end{array}$ & [122] \\
\hline Acacia saligna & Tree seedlings & Giza, Cairo, Egypt & $\begin{array}{l}\text { Mycorrhiza significantly increased plant } \\
\text { height, stem diameter, leaf area, fresh and dry } \\
\text { weights of stems and roots, chlorophyll content }\end{array}$ & [123] \\
\hline Acacia cyclops & Tree seedlings & South Africa & $\begin{array}{l}\text { Both Mycorrhiza and Rhizobium inoculation } \\
\text { increased host biomass and relative growth } \\
\text { rates. Dual inoculation significantly enhanced } \\
\mathrm{N} \text { and P acquisition and utilization rates }\end{array}$ & [124] \\
\hline Prosopis juliflora & Tree seedlings & Semi-arid zones, Mexico & $\begin{array}{c}\text { Prosopis juliflora inoculated with } \\
\text { Glomus aggregatum showed } 41.7 \% \text { intensity } \\
\text { of infection. }\end{array}$ & [125] \\
\hline Prosopis juliflora & Trees & Arid zones, Saudi Arabia & $\begin{array}{l}\text { Prosopis juliflora showed highest root } \\
\text { colonization, spores, soil microbial biomass } \\
\text { and number of nodules compared to the other } \\
11 \text { noninvasive plants }\end{array}$ & [126] \\
\hline Prosopis juliflora & Trees & Arid zones, Saudi Arabia & $\begin{array}{l}\text { Prosopis juliflora encouraged mycorrhiza, } \\
\text { improved the microbial biomass carbon } \\
\text { content and enzymes' activities in soils and } \\
\text { inhibited the growth of other species under } \\
\text { their canopy }\end{array}$ & [65] \\
\hline
\end{tabular}


However, in their review articles, in other ecosystems, Pringle et al., 2009 [115] and Shah et al., 2009 [127] reported some cases in which there was no clear benefit for the invasive plant from the mycorrhizal association. It is clear from the data in Table 2 that the role of mycorrhiza in plant invasiveness in arid and semi-arid regions was undertaken in single species or seedlings in pots and greenhouse experiments, rather than filed studies or whole-system approach research. Similar observations were reported for grasslands, forests, and wetlands [127]. We suggest that more research should be directed towards direct field experiments and studies to stimulate real and natural environments.

\section{Symbiotic Nitrogen Fixation: An Opportunity for Invasive Legumes}

Rhizobia are a group of bacteria, well-known to promote plant growth and form endosymbiotic associations with most plant species in the Leguminosae, and to fix nitrogen through the transformation of atmospheric $\mathrm{N}_{2}$ gas via nitrogenase enzyme [128] into bioavailable N [129-131]. Typically, the invasive plants secure nitrogen, one of the limiting nutrients in arid lands, from symbiotic nitrogen fixation [132,133]. Besides this, some nitrogen-fixing bacteria produce auxins, cytokinins, and gibberellins to enhance plant growth [134] and anti-microbial molecules to protect plants from diseases [135]. Despite the harsh conditions in the arid and semi-arid environments, which reduce the number and soil microbial diversity [136], different strains of rhizobia were reported to withstand severe and extreme conditions, such as salinity and osmotic stresses [130,137-140], temperature [141], drought and soil moisture deficiency [142], soil alkalinity and high $\mathrm{pH}$ [129]. The wide distribution of rhizobia is well documented in arid and semi-arid soils, [143,144] deserts [145], and sand dunes [146]. For instance, Chen et al. (1995) [147] isolated 20 different strains of root nodule bacteria, mainly Rhizobium and Bradyrhizobim species, from the arid saline deserts of China. Moreover, rhizobia could also be found in surface soils [148], and sometimes at a depth of up to $34 \mathrm{~m}$ [149]. The presence of nodules in the roots of invasive woody trees in the arid areas of countries, such as Australia [150,151], Morocco [132], China [147], Saudia Arabia [144,152] and UAE [153], indicates the natural presence of ineffective and effective indigenous rhizobia that nodulate invasive trees in arid environments (Table 3). Besides this, it was also proposed that invasive alien tree species may bring their own symbionts rather than entering into new associations with indigenous rhizobia [33].

Table 3. Studies depicted the role of rhizobia in plant invasion in arid and semi-arid regions.

\begin{tabular}{|c|c|c|c|}
\hline Invasive Host Plant & $\begin{array}{l}\text { Total Number of Genera } \\
\text { or Strains Isolated }\end{array}$ & $\begin{array}{l}\text { Rhizobial spp. } \\
\text { Identified }\end{array}$ & Reference(s) \\
\hline Prosopis farcta & 50 & Ensifer; Mesorhizobium & [154] \\
\hline Prosopis juliflora & 274 & $\begin{array}{l}\text { Achromobacter; Ensifer; } \\
\text { Rhizobium : Sinorhizobium }\end{array}$ & {$[132]$} \\
\hline Prosopis juliflora & 150 & $\begin{array}{l}\text { Rhizobium spp. } \\
\text { Rhizobium leguminosarum }\end{array}$ & {$[129]$} \\
\hline Acacia saligna & 133 & $\begin{array}{c}\text { Rhizobium tropici } \\
\text { Bradyrhizobium japonicum } \\
\text { Bradyrhizobium spp. }\end{array}$ & [150] \\
\hline Acacia saligna & 1 & Bradyrhizobium viridifuturi & [155] \\
\hline Acacia saligna & 1 & Rhizobium & {$[150]$} \\
\hline Acacia saligna & 5 & Rhizobium; Sinorhizobium & [156] \\
\hline Acacia saligna & 7 & $\begin{array}{l}\text { Mesorhizobium; Rhizobium } \\
\text { Bradyrhizobium; Ensifer }\end{array}$ & {$[157]$} \\
\hline Acacia farnesiana & 1 & Sinorhizobium & {$[158]$} \\
\hline Acacia Saligna & 28 & $\begin{array}{l}\text { Rhizobium; } \\
\text { Phyllobacterium }\end{array}$ & [159] \\
\hline $\begin{array}{c}\text { Acacia longifolia; } \\
\text { Acaciacyclops } \\
\text { Acaciamelanoxylon } \\
\text { Acaciasaligna }\end{array}$ & 7 & $\begin{array}{c}\text { Bradyrhizobium; } \\
\text { Azorhizobium } \\
\text { Burkholderia; Ensifer } \\
\text { Methylobacterium } \\
\text { Phyllobacterium }\end{array}$ & {$[151]$} \\
\hline
\end{tabular}

Some invasive trees can cooperate with a wide range of nitrogen-fixing organisms for a successful and effective symbiotic relationship. For instance, the invasive P. juliflora 
could be nodulated by bacteria of different strains, including $\alpha$ and $\beta$ proteobacteria. According to Benata et al. (2008) [132], P. juliflora alone could establish nodulation with more than 274 different rhizobial strains in arid areas of Morocco, and most of these strains tolerate high concentrations of $\mathrm{NaCl}$ up to $500 \mathrm{mM}$. Interestingly, these strains include Sinorhizobium spp., Rhizobium tropici, Rhizobium multihospitium, and Rhizobium giardinii. Comparing rhizobial isolates from Acacia saligna, Acacia seyal, Dalbergia sisso, Macarium tipu, Leucaena leucocephala, and Sesbania sesban, the isolate from invasive Acacia saligna showed the best performance in most of the following parameters: minimum inhibitory $\mathrm{Na}$-azide concentration of $15 \mu \mathrm{g} / \mathrm{ml}$, resistance to four different antibiotics, growth in high temperatures up to $40{ }^{\circ} \mathrm{C}$, and tolerance of salt $(\mathrm{NaCl})$ concentration up to $4 \%$, compared to other non-invasive species [160].

The process of biological nitrogen fixation in invasive species was reported to be a significant factor in their invasion process [145,161], which assists in their growth and development and offers a competitive advantage over non- or slow-responsive nitrogenfixing plants [162,163]. Moreover, Stock et al., (1995) [161] reported that the nodulation and nitrogen fixation of invasive Acacia species (A. cyclops and A. saligna) was a significant factor in their establishment, persistence, and successful competition with local flora. Furthermore, in arid and semi-arid lands, Acacia farnesiana (previously A. smallii) was identified as a serious invader [164] and was also reported to be a potentially high $\mathrm{N}_{2-}$ fixer [158]. It has been reported that symbiotic rhizobia isolated from invasive plants introduced into hot tropical areas tolerate a wide range of stresses. For example, Otieno et al., (2017) [129] isolated 150 Rhizobium strains from the roots of P. juliflora, which showed wide diversity in their tolerance to $\mathrm{NaCl}(1-5 \%)$ and $\mathrm{pH}$ (4-10 units), and intrinsic antibiotic resistance. This wide diversity gives such invasive species some ecological and competitive advantages [165] due to the increase in the nitrogen content in plant tissues and the general improvement of soil health [166]. Such a large range of associations made by invasive species with microsymbionts may have a negative impact on the interaction networks of the indigenous species, whereby invasive species dominate in these areas. Interestingly, invasive plants tend to form an indeterminate type of nodules [129], giving them the ability to tolerate harsh stress conditions more than species with globose determinate types of nodules [167]. Comparing the invasive A. saligna with the other four Acacia spp. [157] determined that the invasive species were nodulated by a higher diversity of taxonomical groups, Mesorhizobium mediterraneum, Rhizobium tropici, Rhizobium sp., Bradyrhizobium sp., and Sinorhizobium meliloti. In general, invasive nitrogen-fixing plants influence soil nutrient dynamics; they increase soil organic matter, soil nitrogen mineralization, and nitrification rates, and consequently affect soil nutrient availability in their rhizosphere $[168,169]$.

In the arid areas of Saudi Arabia, the invasive P. juliflora showed higher values for soil microbial biomass carbon ( $85.3 \mu \mathrm{g} \mathrm{g}^{-1}$ soil), total number of spores (170 spores $100 \mathrm{~g}^{-1}$ soil), root colonization $(65 \%)$, and the number of nodules $\left(12\right.$ seedling $\left.^{-1}\right)$ in response to rhizobia and mycorrhiza compared to the other 11 noninvasive plants [170]. Moreover, it was reported that dual inoculation of Acacia longifolia, an invasive species in the Mediterranean region, significantly improved the growth of the plants [171]. The synergistic benefits of the dual inoculation of invasive legumes with both mycorrhiza fungi and rhizobia improved growth and increased the chances for invasion of alien leguminous species [124]. Furthermore, Ndoye et al., (2015) [172] suggested that co-inoculation with suitable strains of mycorrhiza and nitrogen-fixing bacteria is needed to ensure good plant growth and better $\mathrm{P}$ use efficiency so as to enhance atmospheric nitrogen fixation under limited phosphorus supply conditions.

\section{Pathogens: Invasive Species Protection and Strong Weapon to Suppress Native Species}

Soil pathogens often suppress the growth, productivity, and survival of plants, reduce the relative abundance of species in communities, mediate competitive interactions and affect succession $[173,174]$. In arid lands, the vast success of invasive species such as Acacia dealbata [175,176], Prosopis juliflora [7,62], Ailanthus altissima [177] and Typha angustifo- 
lia [178] in the introduced ranges has been attributed to their ability to release allelopathic compounds that affect native plant species, and soil microbiota, which contribute to the process of invasion [176].

Invasive plants can escape from the inhibitory effects of soil pathogens by different strategies [87,174]; hence, invasive plants will have a better competitive chance through relief from the negative feedback carried out by the native species. Invasive species can harbor endophytes that improve immunity; for instance, in an arid land, the association between invasive Acacia farnesiana and Methylobacterium sp. improves the antioxidant defense and energy balance [88]. Another defense mechanism in invasive trees and shrubs of Acacia is the secretion of gum after natural or artificial injuries in the stem and branches [179]. Shehu et al., (2018) [180] found that Arabic gum significantly inhibited the growth of E. coli and Pseudomonas aeruginosa, and they suggested that it could serve as an antibacterial agent. Moreover, naturally synthesized nanoparticles of silver and copper in gum possessed antimicrobial activity against E. coli, S. aureus, and Micrococcus luteus strains, and have several potential therapeutic and pharmaceutical applications [181].

Prosopis juliflora is the most studied invasive species in the arid zone, with a very strong inhibitory effect on a wide range of microbes that cause diseases to plants, humans, and animals. For instance, extracts of leaves and flowers of $P$. juliflora were inhibitory for the following genera: Botrytis, and Candida [182], Escherichia, Shigella, Salmonella, Proteus, Pseudomonas, Klebsiella, Enterococcus, Listeria, and Bacillus [183], and Escherichia, Staphylococcus, and Candida [184]. In addition, Mazinani et al. (2017) [185] were able to isolate 32 strains from Prosopis juliflora, some of which were able to grow well at $25-50{ }^{\circ} \mathrm{C}, \mathrm{pH}=6-9$, and could tolerate up to $10 \% \mathrm{NaCl}$. In addition, some of these strains showed very strong antimicrobial activities and inhibited the growth of Aspergillus, Saccharomyces, Candida, Escherichia, Staphylococcus, Pseudomonas, Bacillus, Salmonella and Streptococcus [185]. Moreover, eight endophytic fungi were isolated from the invasive Opuntia dillenii; seven showed antibacterial activities against at least one of Bacillus, Escherichia, Pseudomonas or Staphylococcus; the most active endophytes were identified as Fusarium and Aspergillus [54]. Furthermore, Mdee et al., (2009) [186] found that acetone extracts of invasive species Solanum mauritianum and Lantana camara significantly inhibited the growth of different phytopathogenic fungi-Penicillium, Aspergillus, Colletotrichum, Fusarium, Trichoderma, Phytophthora, Pythium and Rhizoctonia.

\section{Allelochemicals: Promotion of Invasive Plants and Native Attack}

In arid regions, several invasive tree species, such as Acacia saligna, Acacia dealbata, Leucanea leucocephala, Prosopis juliflora and Salvia verbenaca, produce allelopathic compounds that interfere with local flora $[117,176]$. It is well documented that the allelochemicals naturally produced by invasive plants such as $P$. juliflora $[7,10,65,187,188]$, Acacia saligna [189], Tamarix aphylla [190] and Acacia dealbata [176] significantly inhibited the seed germination and/or growth of native plants. Moreover, in arid and semi-arid environments, allelochemicals of Acacia dealbata significantly modified soil bacterial activities and reduced the richness and diversity of the bacteria [176]. In addition, P. juliflora leaf extract revealed a significant antimicrobial activity [183,184].

The negative impacts of the toxicity of allelopathic compounds produced by invasive plants differ in effects on germination inhibition, seedling establishment, root elongation and cell division, length of shoots and roots, root volume, limitation of nutrients and /or water supply to shoots, and shoot growth, and they also change the morphology of the host plant, change the root structure, and may induce abnormal growth $[10,126,184,188,191]$. The damaging effect of allelochemicals of invasive plants is not confined to native plants, but it also negatively affects the native microbial community and other microbes, including beneficial microorganisms associated with native plants. For example, allelochemical compounds were reported to significantly reduce the performance of the mutualistic mycorrhizal fungi associated with native plants, hence reducing their growth [192]. As expected, invasive plants produce more allelopathic compounds than native species [33,193], and the 
inhibitory effect of these chemicals vary depending on the part of the invasive plant, i.e., root, stem, leaf flower, or fruit $[188,191]$.

Allelopathy is considered one of the key strategies for successful plant invasiveness $[10,65,194]$. The symbiotic relationship between invasive plants and mycorrhizae, rhizobia and fungal endophytes can stimulate or inhibit the interaction with consumers, pathogens, and competitors $[126,195]$. Several studies have reported that allelopathic compounds produced by invasive plants disrupt the mutualistic relationship between soil rhizobia and several leguminous species by reducing rhizobial population growth [196,197]. In general, allelochemicals significantly reduce the number and weight of developed nodules. However, Alford et al., (2009) [198] reported that the nodulation of some plants, such as Astragalus bisulcatus, Psoralidium tenuiflorum, Medicago sativa, and Sphaerophysa salsula, were not affected by allelochemicals produced by the invasive Acroptilon repens. Moreover, they noticed that the rhizobia present in nodules are more protected from allelochemicals than those living free in the soils. Furthermore, in invasive plants, symbiosis improves the plant antioxidant system and provides the energy required for the host under stress conditions [111], and consequently affects allelochemical production in favor of the invasive plant [199]. Furthermore, Ma et al., (2009) [194] isolated two allelochemicals, namely, 3-3'-5-Trihydroxy4'-7-dimethoxy flavone and 3-3'-5-Trihydroxy-4'-7-dimethoxy flavone-3-O-sulfate, from Ipomoea cairica, the most invasive alien species in China. The individual or joint application of these two allelochemicals inhibited the seed germination of four native plants. Moreover, the soil in the rhizosphere of $P$. juliflora was reported to contain higher levels of total phenolics and L-tryptophan than soils away from the rhizosphere [188]. In response to the allelopathic compounds produced by invasive species, native plants could be very sensitive, moderately sensitive, or tolerant [200]. When native plants fail to tolerate the new chemicals, the invasive plant species will quickly dominate in the invaded area [201].

Comparing the effects of extracts from invasive plant $P$. juliflora with non-invasive P. cineraria, Saadoun et al., (2014) [62] observed that extracts of $P$. juliflora significantly inhibited the growth of Bacillus, Escherichia Pseudomonas, and Staphylococcus, as well as the seed germination of two desert plants, Halocnomum strobilacum and Halopoplis perfoliata. Moreover, extracts of Ailanthus altissima have been proven to be used as an environmentally friendly and promising method to control harmful algal blooms caused by Microcystis aeruginosa [202]. In addition, Filippou et al., (2014) [76] isolated Ailanthone, a major plant inhibiter, from the invasive Ailanthus altissima, which significantly inhibited plant growth of Brassica juncea, Eragrostis tef, and Lemna minor.

\section{Microbial Changes under Invasive Species: Self-Defense and Native Distraction}

In arid lands, invasive plants can alter the structure of different native ecosystems and threaten native aboveground and underground biodiversity $[69,203,204]$. For example, invasion by the Australian Acacia longifolia [63], Prosopis juliflora [64,65], and Kalanchoe daigremontiana [66] significantly altered the characteristics of vegetation, as well as the diversity and structure of microbes, in their rhizosphere. Moreover, invasive plants can potentially modify the native soil environment and consequently influence the composition and density of the native microbes, which in turn influences the invasiveness of species in the invaded area $[50,127,205,206]$. Further, invasion of Pennisetum setaceum in semi-arid areas significantly modified the structure and composition of the native soil microbial community and the enzyme activity related to nitrogen cycling, which may potentially alter the function of the invaded ecosystem [47].

In their interactions with indigenous soil communities, invasive plant species can profoundly negatively affect native species $[65,207]$. To explore these interactions, Inderjit and Putten (2010) [208] proposed three pathways: plant-soil feedback interactions, manipulation of native soil biota by enhancing pathogens, and production of complex allelochemicals toxic to native plants and which cannot be degraded by local soil microbes. In their meta-analysis, Zhang et al., (2019) [46] found that invasive plants increased bacte- 
rial biomass and microbivore abundance compared to native species. Moreover, a wide range of bacterial communities were reported in the rhizospheres of two invasive species, namely, Prosopis juliflora and Parthenium hysterophorus, where both species harbored more diversified bacterial communities from different phyla compared to the bulk soil [61]. The same authors found that the most predominant genera in the rhizosphere of $P$. juliflora were Acidobacteria, Bacteriodetes and Gammaproteobacteria, whereas Acidobacteria, Betaproteobacteria, and Nitrospirae dominated the rhizosphere of the P. hysterophorus.

The composition and structure of the mycorrhizal community in the rhizosphere of invasive species Acacia dealbata [69,70] and Bromus tectorum [71] were significantly modified and disturbed, and both invasive species prohibited the establishment and growth of native species. According to Phillips et al., (2019) [116], invasive grasses had an abundance of symbiotic mycorrhiza and other types of fungi compared to the native shrubs. They concluded that grass invasion might decrease the availability of beneficial symbionts that protect native species from pathogens. Moreover, the allelopathic effects of the invasive P. juliflora encouraged mycorrhiza, increased the microbial biomass carbon, inhibited the growth of other species under their canopy [65], and improved enzymatic activity in soils, as well as the nutrient status [64]. The consequences of these modifications may lead to further changes in the structure and function of other microbial species, and consequently, the invader plant can affect ecosystem function $[47,209]$.

Changes in the structure and functions of microorganisms in the rhizosphere of invasive plants in arid lands could be attributed to different factors: (a) increase in the microbial biomass of carbon, (b) improved metabolic activity in the rhizosphere of invasive plants, (c) influence and modification of the enzymatic activity in the rhizosphere of invasive plants, and (d) increased urease and glucosaminidase activities (Table 1 (ii)). In addition, invasive plants can accelerate the change of microorganisms and promote their metabolic activity in the soil by modifying the microclimate. The dense covers and large amounts of litter produced by invasive plants improve soil physical and chemical properties, the quantity and quality of organic matter, and soil moisture, compared to the non-invaded sites $[1,62,66,67]$. In low-input agroecosystems such as arid and semi-arid soils, where both $\mathrm{N}$ and P content are typically low, the inoculum application of exotic and/or native PGP microorganisms is recommended to improve ecosystem productivity $[65,210]$. Applications of microbial inocula, such as biofertilizers, Phytostimulation and biological control agents, are encouraged to increase crop production and foster the restoration of degraded arid lands [139]. However, deliberate introductions of exotic plants for rehabilitation, and selected strains for improving productivity or to control pests and diseases, may lead to major positive or negative changes in the microbial composition and diversity $[1,211]$. The diversity and functions of microbes of native communities could be affected directly by competitions, antagonistic and synergic interactions with newly added microbes, or indirectly by the amount of the exudates secreted along the root with enhanced growth [212]. In addition, imported exotic PGP microbial inoculants might facilitate the invasion of new microbial species, and alter or suppress the resident microbial communities, hindering ecosystems' recovery [211].

\section{Conclusions}

In arid and semi-arid areas, invasive plant species harbor hundreds of endophytes and initiate positive interactions with rhizospheric microorganisms to ensure growth and increase tolerance to environmental stressors. In low-resource arid environments, invasive plants tend to form associations with mycorrhizal fungi to increase the absorption of nutrients and enhance plant tolerance to different environmental stresses. In addition, invasive leguminous trees can adopt a wide range of nitrogen-fixing organisms for successful and effective symbiotic relationships in order to survive, improve establishment, and tolerate adverse conditions. Endophytes, PGP microbes, and their secondary metabolites alter the aboveground and belowground ecosystem structure and function, encouraging invasive plant species to invade new areas. Moreover, invasive plants adopt allelopathic 
mechanisms to enhance self-defense and distract native organisms. The allelochemicals significantly modify soil microbial activities and reduce the richness and diversity of native microorganisms and aboveground flora. Furthermore, invasive plants avoid the inhibitory effects of soil pathogens by harboring endophytes that improve immunity and gum production, in addition to their ability to release allelopathic compounds.

In arid and semi-arid areas, alien plant species contribute significantly to the diversity and numbers of autochthonous organisms and native flora. This, in turn, will significantly impact the ecosystem, which complicates and hampers the sustainability of these organisms and the processes in the whole ecosystem. It is well noted that most of the research carried out is sporadic and covers certain areas of interest, such as allelopathic effects, the role of specific microorganisms in plant nutrition or infection, and the extraction of novel antibacterial and antifungal products. Therefore, there is a real need for interdisciplinary research to explore the role of microbes in the invasion process and the mitigation of biotic and abiotic stresses in invasive plants across different climatic zones, to control and prevent the invasion into new areas. Moreover, the use of modern biotechnological and molecular tools, field experiments, and meta-analyses of data to attain high ecological validity that will sustain the integrity and function of arid and semi-arid ecosystems, are all needed too.

Author Contributions: Conceptualization, E.A.E.E., A.E.-K. and K.A.M.; writing-original draft preparation, E.A.E.E., A.E.-K. and K.A.M.; writing-review and editing, E.A.E.E., A.E.-K., K.A.M., A.I.O. and I.S. All authors have read and agreed to the published version of the manuscript.

Funding: This research received no external funding.

Institutional Review Board Statement: Not applicable.

Informed Consent Statement: Not applicable.

Data Availability Statement: Not applicable.

Conflicts of Interest: The authors declare no conflict of interest.

\section{References}

1. Milton, S.; Dean, W. Plant invasions in arid areas: Special problems and solutions: A South African perspective. Biol. Invasions 2010, 12, 3935-3948. [CrossRef]

2. Daffonchio, D.; Hirt, H.; Berg, G. Plant-microbe interactions and water management in arid and saline soils. In Principles of Plant-Microbe Interactions; Lugtenberg, B., Ed.; Springer: Cham, Switzerland, 2015.

3. Chen, E.; Liao, H.; Chen, B.; Peng, S. Arbuscular mycorrhizal fungi are a double-edged sword in plant invasion controlled by phosphorus concentration. New Phytol. 2020, 226, 295-300. [CrossRef]

4. Abid, M.; Zhang, Y.J.; Li, Z.; Bai, D.F.; Zhong, Y.P.; Fang, J.B. Effect of salt stress on growth, physiological and biochemical characters of Four kiwifruit genotypes. Sci. Hortic. 2020, 271, 109473. [CrossRef]

5. Wang, Y. Terrestrial Ecosystems and Biodiversity; CRC Press: Milton, UK, 2020.

6. El-Keblawy, A.; Ksiksi, T. Artificial forests as conservation sites for the native flora of the UAE. Ecol. Manag. 2005, 213, 288-296. [CrossRef]

7. El-Keblawy, A.; Al-Rawai, A. Impacts of the invasive exotic Prosopis juliflora (Sw.) D.C. on the native flora and soils of the UAE. Plant Ecol. 2007, 190, 23-35. [CrossRef]

8. Hussain, M.I.; Tsombou, F.M.; El-Keblawy, A. Surface canopy position determines the photosystem II photochemistry in invasive and native Prosopis congeners at Sharjah Desert, UAE. Forests 2020, 11, 740. [CrossRef]

9. Dakhil, M.A.; El-Keblawy, A.; El-Sheikh, M.A.; Halmy, M.W.A.; Ksiksi, T.; Hassan, W.A. Global Invasion Risk Assessment of Prosopis juliflora at Biome Level: Does Soil Matter? Biology 2021, 10, 203. [CrossRef]

10. El-Keblawy, A.; Abdelfatah, M.A. Impacts of native and invasive exotic Prosopis congeners on soil properties and associated flora in the arid United Arab Emirates. J. Arid Environ. 2014, 100-101, 1-8. [CrossRef]

11. Collins, C.D.; Bever, J.D.; Hersh, M.H. Community context for mechanisms of disease dilution: Insights from linking epidemiology and plant-soil feedback theory. Ann. N. Y. Acad. Sci. 2020, 1469, 65. [CrossRef] [PubMed]

12. van Wilgen, N.J.; van Wilgen, B.W.; Midgley, G.F. Biological invasions as a component of South Africa's global change research effort. In Biological Invasions in South Africa. Invading Nature-Springer Series in Invasion Ecology; Van Wilgen, B., Measey, J., Richardson, D., Wilson, J., Zengeya, T., Eds.; Springer: Cham, Switzerland, 2020; Volume 14, p. 855. [CrossRef]

13. Simberloff, D. Non-native Species DO Threaten the Natural Environment. J. Agric. Environ. Ethics. 2005, 18, 595-607. [CrossRef]

14. Richardson, D.M.; Rejmánek, M. Trees and shrubs as invasive alien species-A global review. Divers. Distrib. 2011, 17, 788-809. [CrossRef] 
15. Edrisi, S.A.; El-Keblawy, A.; Abhilash, P.C. Sustainability Analysis of Prosopis juliflora (Sw.) DC Based Restoration of Degraded Land in North India. Land 2020, 9, 59. [CrossRef]

16. Hussain, M.I.; Shackleton, R.T.; El-Keblawy, A.; Del Mar Trigo Pérez, M.; González, L. Invasive Mesquite (Prosopis juliflora), an Allergy and Health Challenge. Plants 2020, 9, 141. [CrossRef] [PubMed]

17. Kumar Rai, P.; Singh, J.S. Invasive alien plant species: Their impact on environment, ecosystem services and human health. Ecol. Indic. 2020, 111, 106020. [CrossRef] [PubMed]

18. Gordon, D.R. Effects of invasive, non-indigenous plant species on ecosystem processes: Lessons from Florida. Ecol. Appl. 1998, 8, 975-989. [CrossRef]

19. Abdallah, M.A.B.; Durfee, N.; Mata-González, R.; Ochoa, C.G.; Noller, J.S. Water use and soil moisture relationships on western juniper trees at different growth stages. Water 2020,12, 1596. [CrossRef]

20. Mata-González, R.; Abdallah, M.A.B.; Ochoa, C.G. Water use by mature and sapling western juniper (Juniperus occidentalis) trees. Rangel. Ecol. Manag. 2021, 74, 110-113. [CrossRef]

21. Zhang, H.; Goncalves, P.; Copeland, E.; Qi, S.; Dai, Z.; Li, G.; Wang, C.; Du, D.; Thomas, T. Invasion by the weed Conyza canadensis alters soil nutrient supply and shifts microbiota structure. Soil Biol. Biochem. 2020, 143, 107739. [CrossRef]

22. Hu, Z.; Li, J.; Shi, K.; Ren, G.; Dai, Z.; Sun, J.; Zheng, X.; Zhou, Y.; Zhang, J.; Li, G.; et al. Effects of Canada Goldenrod Invasion on Soil Extracellular Enzyme Activities and Ecoenzymatic Stoichiometry. Sustainability 2021, 13, 3768. [CrossRef]

23. Hejda, M.; Pysek, P.; Jarosik, V. Impact of Invasive Plants on the Species Richness, Diversity and Composition of Invaded Communities. J. Ecol. 2009, 97, 393-403. [CrossRef]

24. Abdallah, M.A.B.; Mata-González, R.; Noller, J.S.; Ochoa, C.G. Effects of western juniper (Juniperus occidentalis) control on ecosystem nitrogen stocks in central Oregon, USA. J. Plant Ecol. 2021, 14, 1073-1089. [CrossRef]

25. Gioria, M.; Osborne, B.A. Resource competition in plant invasions: Emerging patterns and research needs. Front. Plant Sci. 2014, 5, 501. [CrossRef]

26. Koutika, L.; Richardson, D.M. Acacia mangium Willd: Benefits and threats associated with its increasing use around the world. For. Ecosyst. 2019, 6, 2. [CrossRef]

27. Callaway, R.M.; Walker, L.R. Competition and Facilitation: A Synthetic Approach to Interactions in Plant Communities. Ecology 1997, 78, 1958. [CrossRef]

28. Barea, J.M.; Palenzuela, J.; Cornejo, P.; Sánchez-Castro, I.; Navarro-Fernández, C.; Lopéz-García, A.; Estrada, B.; Azcón, R.; Ferrol, N.; Azcón-Aguilar, C. Ecological and functional roles of mycorrhizas in semi-arid ecosystems of Southeast Spain. J. Arid Environ. 2011, 75, 1292-1301. [CrossRef]

29. Aroca, R.; Ruiz-Lozano, J.M. Induction of Plant Tolerance to Semi-arid Environments by Beneficial Soil Microorganisms-A Review. In Climate Change, Intercropping, Pest Control and Beneficial Microorganisms; Springer: Dordrecht, The Netherlands, 2009; pp. 121-135.

30. Verma, V.; Ravindran, P.; Kumar, P.P. Plant hormone-mediated regulation of stress responses. BMC Plant Biol. 2016, 16, 86. [CrossRef]

31. Yu, Z.; Duan, X.; Luo, L.; Dai, S.; Ding, Z.; Xia, G. How Plant Hormones Mediate Salt Stress Responses. Trends Plant Sci. 2020. Available online: https://pubmed.ncbi.nlm.nih.gov/32675014/ (accessed on 11 November 2021). [CrossRef]

32. Ramirez, K.S.; Snoek, L.B.; Koorem, K.; Geisen, S.; Bloem, L.J.; ten Hooven, F.; Kostenko, O.; Krigas, N.; Manrubia, M.; Caković, D.; et al. Range-expansion effects on the belowground plant microbiome. Nat. Ecol. Evol. 2019, 3, 604-611. [CrossRef]

33. Reinhart, K.O.; Callaway, R.M. Soil Biota and Invasive Plants. New Phytol. 2006, 170, 445-457. [CrossRef]

34. Richardson, D.M.; Allsopp, N.; D’antonio, C.M.; Milton, S.J.; Rejmánek, M. Plant invasions-The role of mutualisms. Biol. Rev. Camb. Philos. Soc. 2000, 75, 65-93. [CrossRef]

35. Khare, E.; Mishra, J.; Arora, N.K. Multifaceted interactions between endophytes and plant: Developments and prospects. Front. Microbiol. 2018, 9, 2732. [CrossRef]

36. Porras-Alfaro, A.; Raghavan, S.; Garcia, M.; Sinsabaugh, R.L.; Natvig, D.O.; Lowrey, T.K. Endophytic Fungal Symbionts Associated with Gypsophilous Plants; National Research Council of Canada: Ottawa, ON, Canada, 2014; pp. 295-301.

37. Knapp, D.G.; Pintye, A.; Kovács, G.M. The dark side is not fastidious-Dark septate endophytic fungi of native and invasive plants of semiarid sandy areas. PLoS ONE 2012, 7, e32570. [CrossRef] [PubMed]

38. Xu, L.; Zhou, L.; Zhao, J.; Li, J.; Li, X.; Wang, J. Fungal endophytes from Dioscorea zingiberensis rhizomes and their antibacterial activity. Lett. Appl. Microbiol. 2008, 46, 68-72. [CrossRef]

39. Kelemu, S.; White, J.F.; Munoz, F.; Takayama, Y. An endophyte of the tropical forage grass Brachiaria brizantha: Isolating, identifying, and characterizing the fungus, and determining its antimycotic properties. Can. J. Micobiol. 2001, 47, 55-62. [CrossRef]

40. Mitchell, C.E.; Agrawal, A.A.; Bever, J.D.; Gilbert, G.S.; Hufbauer, R.A.; Klironomos, J.N.; Maron, J.L.; Morris, W.F.; Parker, I.M.; Power, A.G.; et al. Biotic interactions and plant invasions. Ecol. Lett. 2006, 9, 726-740. [CrossRef]

41. Coats, V.C.; Rumpho, M.E. The rhizosphere microbiota of plant invaders: An overview of recent advances in the microbiomics of invasive plants. Front. Microbiol. 2014, 5, 368. [CrossRef] [PubMed]

42. Mateos Naranjo, E.; Mesa, J.; Pajuelo, E.; Pérez Martín, A.; Caviedes, M.A.; Rodríguez Llorente, I.D. Deciphering the role of plant growth-promoting rhizobacteria in the tolerance of the invasive cordgrass Spartina densiflora to physicochemical properties of salt-marsh soils. Plant Soil. 2015, 394, 45-55. [CrossRef] 
43. Dawson, W.; Schrama, M.; Austin, A. Identifying the role of soil microbes in plant invasions. J. Ecol. 2016, 104, 1211-1218. [CrossRef]

44. Ravichandran, K.R.; Thangavelu, M. Role and influence of soil microbial communities on plant invasion. Ecol. Quest. 2017, 27, 9. [CrossRef]

45. Keet, J.; Ellis, A.G.; Hui, C.; Le Roux, J.J. Legume-Rhizobium symbiotic promiscuity and effectiveness do not affect plant invasiveness. Ann. Bot. 2017, 119, 1319-1331. [CrossRef]

46. Zhang, P.; Li, B.; Wu, J.; Hu, S.; Seabloom, E. Invasive plants differentially affect soil biota through litter and rhizosphere pathways: A meta-analysis. Ecol. Lett. 2019, 22, 200-210. [CrossRef]

47. Rodríguez-Caballero, G.; Caravaca, F.; Alguacil, M.M.; Fernández-López, M.; Fernández-González, A.J.; Roldán, A. Striking alterations in the soil bacterial community structure and functioning of the biological $\mathrm{N}$ cycle induced by Pennisetum setaceum invasion in a semiarid environment. Soil Biol. Biochem. 2017, 109, 176-187. [CrossRef]

48. Soti, P.G.; Purcell, M.; Jayachandran, K. Soil biotic and abiotic conditions negate invasive species performance in native habitat. Ecol. Process. 2020, 9, 18. [CrossRef]

49. Zhang, J.; He, X.L.; Zhao, L.L.; Xu, W.; Yan, J. Responses of desert soil factors and dark septate endophytes colonization to clonal plants invasion. Acta Ecol. Sin. 2015, 35, 1095.

50. de Souza, T.; Santos, D.; de Andrade, L.; Freitas, H. Plant-soil feedback of two legume species in semi-arid Brazil. Braz. J. Microbiol. 2019, 50, 1011-1020. [CrossRef]

51. Lugo, M.; Reinhart, K.; Menoyo, E.; Crespo, E.; Urcelay, C. Plant functional traits and phylogenetic relatedness explain variation in associations with root fungal endophytes in an extreme arid environment. Mycorrhiza 2015, 25, 85-95. [CrossRef] [PubMed]

52. Coleman-Derr, D.; Desgarennes, D.; Fonseca-Garcia, C.; Gross, S.; Clingenpeel, S.; Woyke, T.; North, G.; Visel, A.; Partida-Martinez, L.P.; Tringe, S.G. Plant compartment and biogeography affect microbiome composition in cultivated and native Agave species. New. Phytol. 2016, 209, 798-811. [CrossRef]

53. Khidir, H.H.; Eudy, D.M.; Porras-Alfaro, A.; Herrera, J.; Natvig, D.O.; Sinsabaugh, R.L. A general suite of fungal endophytes dominate the roots of two dominant grasses in a semiarid grassland. J. Arid Environ. 2010, 74, 35-42. [CrossRef]

54. González-Teuber, M.; Urzúa, A.; Morales, A.; Ibáñez, C.; Bascuñán-Godoy, L. Benefits of a root fungal endophyte on physiological processes and growth of the vulnerable legume tree Prosopis chilensis (Fabaceae). J. Plant Ecol. 2019, 12, 264-271. [CrossRef]

55. González-Menéndez, V.; Crespo, G.; de Pedro, N.; Diaz, C.; Martín, J.; Serrano, R.; Mackenzie, T.A.; Justicia, C.; González-Tejero, M.R.; Casares, M.; et al. Fungal endophytes from arid areas of Andalusia: High potential sources for antifungal and antitumoral agents. Sci. Rep. 2018, 8, 9729. [CrossRef] [PubMed]

56. Loro, M.; Valero-Jiménez, C.A.; Nozawa, S.; Márquez, L.M. Diversity and composition of fungal endophytes in semiarid Northwest Venezuela. J. Arid Environ. 2012, 85, 46-55. [CrossRef]

57. Burlak, O.P.; de Vera, J.; Yatsenko, V.; Kozyrovska, N.O. Putative mechanisms of bacterial effects on plant photosystem under stress. Biopolim. Cell 2013, 29, 3-10. [CrossRef]

58. Wani, Z.A.; Ashraf, N.; Mohiuddin, T.; Riyaz-Ul-Hassan, S. Plant-endophyte symbiosis, an ecological perspective. Appl. Microbiol. Biotechnol. 2015, 99, 2955-2965. [CrossRef] [PubMed]

59. Kulkarni, S.; Nautiyal, C.S. Characterization of high temperature-tolerant rhizobia isolated from Prosopis juliflora grown in alkaline soil. J. Gen. Appl. Microbiol. 1999, 45, 213-220. [CrossRef] [PubMed]

60. Ratnaweera, P.B.; de Silva, E.D.; Williams, D.E.; Andersen, R.J. Antimicrobial activities of endophytic fungi obtained from the arid zone invasive plant Opuntia dillenii and the isolation of equisetin, from endophytic Fusarium sp. BMC Complement. Altern. Med. 2015, 15, 220. [CrossRef]

61. Jothibasu, K.; Chinnadurai, C.; Sundaram, S.P.; Kumar, K.; Balachandar, D. Molecular Profiling of Rhizosphere Bacterial Communities Associated with Prosopis juliflora and Parthenium hysterophorus. J. Microbiol. Biotechnol. 2012, 22, 301-310. [CrossRef]

62. Saadoun, I.; Ahmad, A.; Nasir, A.; Al-Joubori, B.; El-Keblawy, A. Effect of Invasive and Native Prosopis Plants from Deserts of the UAE on Soil Microbiota and Seed Germination of Desert Plants. Int. J. Life Sci. Med. Res. 2014, 4, 1-8. [CrossRef]

63. Marchante, E.; Marchante, H.; Freitas, H.; Kjøller, A.; Struwe, S. Decomposition of an N-fixing invasive plant compared with a native species: Consequences for ecosystem. Agric. Ecosyst. Environ. Appl. Soil Ecol. 2019, 138, 19-31. [CrossRef]

64. Vallejo, V.E.; Arbeli, Z.; Terán, W.; Lorenz, N.; Dick, R.P.; Roldan, F. Effect of land management and Prosopis juliflora (Sw.) DC trees on soil microbial community and enzymatic activities in intensive silvopastoral systems of Colombia. Agric. Ecosys. Environ. 2012, 150, 139-148. [CrossRef]

65. Mahdhi, M.; Tounekti, T.; Khemira, H. Effects of Prosopis juliflora on germination, plant growth of Sorghum bicolor, mycorrhiza and soil microbial properties. Allelopath. J. 2019, 46, 121-132. [CrossRef]

66. Herrera, I.; Ferrer-Paris, J.R.; Benzo, D.; Flores, S.; García, B.; Nassar, J.M. An Invasive Succulent Plant (Kalanchoe daigremontiana) Influences Soil Carbon and Nitrogen Mineralization in a Neotropical Semiarid Zone. Pedosphere 2018, 28, 632-643. [CrossRef]

67. Dawkins, K.; Esiobu, N. The Invasive Brazilian Pepper Tree (Schinus terebinthifolius) Is Colonized by a Root Microbiome Enriched with Alphaproteobacteria and Unclassified Spartobacteria. Front. Microbiol. 2018, 9, 876. [CrossRef] [PubMed]

68. Cibichakravarthy, B.; Preetha, R.; Sundaram, S.; Kumar, K.; Balachandar, D. Diazotrophic diversity in the rhizosphere of two exotic weed plants, Prosopis juliflora and Parthenium hysterophorus. World J. Microbiol. Biotechnol. 2012, 28, 605-613. [CrossRef] [PubMed] 
69. Lorenzo, P.; Rodríguez-Echeverría, S.; González, L.; Freitas, H. Effect of invasive Acacia dealbata Link on soil microorganisms as determined by PCR-DGGE. Agric. Ecosyst. Environ. Appl. Soil Ecol. 2010, 44, 245-251. [CrossRef]

70. Guisande-Collazo, A.; González, L.; Souza-Alonso, P. Impact of an invasive nitrogen-fixing tree on arbuscular mycorrhizal fungi and the development of native species. AoB Plants 2016, 8, plw018. [CrossRef] [PubMed]

71. Hawkes, C.V.; Belnap, J.; D'antonio, C.; Firestone, M.K. Arbuscular mycorrhizal assemblages in native plant roots change in the presence of invasive exotic grasses. Plant Soil. 2006, 281, 369-380. [CrossRef]

72. Carvalho, L.M.; Antunes, P.M.; Martins-Loução, M.A.; Klironomos, J.N. Disturbance influences the outcome of plant-soil biota interactions in the invasive Acacia longifolia and in native species. Oikos 2010, 119, 1172-1180. [CrossRef]

73. Srivastava, A.; Anandrao, R.K. Antimicrobial potential of fungal endophytes isolated from leaves of Prosopis juliflora (SW.) DC. an important weed. Int. J. Pharm. Pharm. 2015, 7, 128-136.

74. Ortiz, N.; Armada, E.; Duque, E.; Roldán, A.; Azcón, R. Contribution of arbuscular mycorrhizal fungi and/or bacteria to enhancing plant drought tolerance under natural soil conditions: Effectiveness of autochthonous or allochthonous strains. J. Plant Physiol. 2015, 174, 87-96. [CrossRef]

75. Li, G.; Kim, S.; Han, S.H.; Chang, H.; Du, D.; Son, Y. Precipitation affects soil microbial and extracellular enzymatic responses to warming. Soil Biol. Biochem. 2018, 120, 212-221. [CrossRef]

76. Filippou, P.; Bouchagier, P.; Skotti, E.; Fotopoulos, V. Proline and reactive oxygen/nitrogen species metabolism is involved in the tolerant response of the invasive plant species Ailanthus altissima to drought and salinity. Environ. Exp. Bot. 2014, 97, 1-10. [CrossRef]

77. Khan, A.L.; Hussain, J.; Al-Harrasi, A.; Al-Rawahi, A.; Lee, I. Endophytic fungi: Resource for gibberellins and crop abiotic stress resistance. Crit. Rev. Biotechnol. 2015, 35, 62-74. [CrossRef]

78. Ren, C.; Dai, C. Jasmonic acid is involved in the signaling pathway for fungal endophyte-induced volatile oil accumulation of Atractylodes lancea plantlets. BMC Plant Boil. 2012, 12, 128. [CrossRef] [PubMed]

79. Khan, M.U.; Sessitsch, A.; Harris, M.; Fatima, K.; Imran, A.; Arslan, M.; Shabir, G.; Khan, Q.M.; Afzal, M. Cr-resistant rhizo-and endophytic bacteria associated with Prosopis juliflora and their potential as phytoremediation enhancing agents in metal-degraded soils. Front. Plant Sci. 2015, 5, 755. [CrossRef]

80. Waqas, M.; Khan, A.L.; Kamran, M.; Hamayun, M.; Kang, S.; Kim, Y.; Lee, I. Endophytic fungi produce gibberellins and indoleacetic acid and promotes host-plant growth during stress. Molecules 2012, 17, 10754-10773. [CrossRef] [PubMed]

81. Rodrigues, R.R.; Pineda, R.P.; Barney, J.N.; Nilsen, E.T.; Barrett, J.E.; Williams, M.A. Plant invasions associated with change in root-zone microbial community structure and diversity. PLoS ONE 2015, 10, e0141424. [CrossRef] [PubMed]

82. Cosme, M.; Lu, J.; Erb, M.; Stout, M.J.; Franken, P.; Wurst, S. A fungal endophyte helps plants to tolerate root herbivory through changes in gibberellin and jasmonate signaling. New Phytol. 2016, 211, 1065-1076. [CrossRef]

83. Dai, Z.; Fu, W.; Wan, L.; Cai, H.; Wang, N.; Qi, S.; Du, D. Different growth promoting effects of endophytic bacteria on invasive and native clonal plants. Front. Plant Sci. 2016, 7, 706. [CrossRef]

84. Yang, Q.; Wei, S.; Shang, L.; Carrillo, J.; Gabler, C.A.; Nijjer, S.; Li, B.; Siemann, E. Mycorrhizal associations of an invasive tree are enhanced by both genetic and environmental mechanisms. Ecography 2015, 38, 1112-1118. [CrossRef]

85. Aslani, F.; Juraimi, A.; Ahmad-Hamdani, M.; Alam, M.; Hasan, M.; Hashemi, F.; Bahram, M. The role of arbuscular mycorrhizal fungi in plant invasion trajectory. Plant Soil. 2019, 441,1-14. [CrossRef]

86. Callaway, R.M.; Ridenour, W.M. Novel Weapons: Invasive Success and the Evolution of Increased Competitive Ability. Front. Ecol. Environ. 2004, 2, 436-443. [CrossRef]

87. Rout, M.E.; Callaway, R.M. Interactions between exotic invasive plants and soil microbes in the rhizosphere suggest that 'everything is not everywhere'. Ann. Bot. 2012, 110, 213-222. [CrossRef] [PubMed]

88. Alcántara-Martínez, N.; Figueroa-Martínez, F.; Rivera-Cabrera, F.; Gutiérrez-Sánchez, G.; Volke-Sepúlveda, T. An endophytic strain of Methylobacterium sp. increases arsenate tolerance in Acacia farnesiana (L.) Willd: A proteomic approach. Sci. Total Environ. 2018, 625, 762-774. [CrossRef] [PubMed]

89. Abdelmoteleb, A.; Troncoso-Rojas, R.; Gonzalez-Soto, T.; González-Mendoza, D. Antifungical Activity of Autochthonous Bacillus subtilis Isolated from Prosopis juliflora against Phytopathogenic Fungi. Mycobiology 2017, 45, 385-391. [CrossRef] [PubMed]

90. Mangla, S.; Callaway, R.M. Exotic Invasive Plant Accumulates Native Soil Pathogens Which Inhibit Native Plants. J. Ecol. 2008, 96, 58-67. [CrossRef]

91. Vilcinskas, A. Pathogens as Biological Weapons of Invasive Species. PLoS Pathog. 2015, 11, e1004714. [CrossRef]

92. Adil, S.; Muneer, M.A.; Imran, M.; Munir, M.Z. Seasonality of arbuscular mycorrhiza and dark septate endophytes in some grasses under arid climatic conditions. J. Agric. Res. 2017, 55, 601-610.

93. Menoyo, E.; Teste, F.P.; Ferrero, M.A.; Lugo, M.A. Associations between fungal root endophytes and grass dominance in arid highlands. Fungal Ecol. 2020, 45, 100924. [CrossRef]

94. Gonzalez Mateu, M.; Baldwin, A.H.; Maul, J.E.; Yarwood, S.A. Dark septate endophyte improves salt tolerance of native and invasive lineages of Phragmites australis. ISME J. 2020, 14, 1943-1954. [CrossRef]

95. Li, X.; He, X.; Hou, L.; Ren, Y.; Wang, S.; Su, F. Dark septate endophytes isolated from a xerophyte plant promote the growth of Ammopiptanthus mongolicus under drought condition. Sci. Rep. 2018, 8, 7896. [CrossRef] 
96. Udaiyan, K.; Karthikeyan, A.; Muthukumar, T. Influence of edaphic and climatic factors on dynamics of root colonization and spore density of vesicular-arbuscular mycorrhizal fungi in Acacia farnesiana Willd. and A. planifrons W.et.A. Trees 1996, $11,65-71$. [CrossRef]

97. Pennisi, E. Fungi Shield New Host Plants from Heat and Drought. Science 2003, 301, 1466-1467. [CrossRef] [PubMed]

98. Jung, S.; Martinez-Medina, A.; Lopez-Raez, J.; Pozo, M. Mycorrhiza-Induced Resistance and Priming of Plant Defenses. J. Chem. Ecol. 2012, 38, 651-664. [CrossRef] [PubMed]

99. Bahadur, A.; Batool, A.; Nasir, F.; Jiang, S.; Mingsen, Q.; Zhang, Q.; Pan, J.; Liu, Y.; Feng, H. Mechanistic Insights into Arbuscular Mycorrhizal Fungi-Mediated Drought Stress Tolerance in Plants. Int. J. Mol. Sci. 2019, 20, 4199. [CrossRef] [PubMed]

100. Wipf, D.; Krajinski, F.; Tuinen, D.; Recorbet, G.; Courty, P. Trading on the arbuscular mycorrhiza market: From arbuscules to common mycorrhizal networks. New Phytol. 2019, 223, 1127-1142. [CrossRef] [PubMed]

101. Funk, J.L. The physiology of invasive plants in low-resource environments. Conser. Physiol. 2013, 1, cot026. [CrossRef]

102. Willis, A.; Rodrigues, B.F.; Harris, P.J.C. The Ecology of Arbuscular Mycorrhizal Fungi. Crit. Rev. Plant Sci. 2013, 32, 1-20. [CrossRef]

103. Elsheikh, E.A.; Mirghani, A.M. Interaction of VA mycorrhizal fungi and root-knot nematode on tomato plants: Effects of nematode inoculum density, soil texture and soil sterilization. Natl. Resour. Environ. 1997, 1, 1-6.

104. Al-Barakah, F.N.; Mridha, M. Status and need of research on arbuscular mycorrhizal fungi and Rhizobium for growth of Acacias. J. Pure Appl. Microbiol. 2014, 8, 129-140.

105. Makarov, M.I. The role of mycorrhiza in transformation of nitrogen compounds in soil and nitrogen nutrition of plants: A review. Eurasian Soil Sci. 2019, 52, 193. [CrossRef]

106. Lumini, E.; Pan, J.; Magurno, F.; Huang, C.; Bianciotto, V.; Xue, X.; Balestrini, R.; Tedeschi, A. Native arbuscular mycorrhizal fungi characterization from Saline Lands in Arid Oases, Northwest China. J. Fungi 2020, 6, 80. [CrossRef]

107. Zhao, M.; Lu, X.; Zhao, H.; Yang, Y.; Hale, L.; Gao, Q.; Liu, W.; Guo, J.; Li, Q.; Zhou, J.; et al. Ageratina adenophora invasions are associated with microbially mediated differences in biogeochemical cycles. Sci. Total Environ. 2019, 677, 47-56. [CrossRef]

108. Mahmoudi, N.; Dias, T.; Mahdhi, M.; Cruz, C.; Mars, M.; Caeiro, M.F. Does Arbuscular Mycorrhiza Determine Soil Microbial Functionality in Nutrient-Limited Mediterranean Arid Ecosystems? Diversity 2020, 12, 234. [CrossRef]

109. Yanfang, B.; Min, L.; Shaoxia, G. Development status of Arbuscular mycorrhizal fungi associated with invasive plant Coreopsis grandiflora Hogg. Afr. J. Microbiol. Res. 2012, 6, 2779-2784. [CrossRef]

110. Dhar, P.; Al-Qarawi, A.; Mridha, M. Arbuscular mycorrhizal fungal association in Asteraceae plants growing in the arid lands of Saudi Arabia. J. Arid Land. 2015, 7, 676-686. [CrossRef]

111. Martínez-García, L.B.; Armas, C.; Miranda, J.d.D.; Padilla, F.M.; Pugnaire, F.I. Shrubs influence arbuscular mycorrhizal fungi communities in a semi-arid environment. Soil Biol. Biochem. 2011, 43, 682-689. [CrossRef]

112. Sun, C.; Johnson, J.M.; Cai, D.; Sherameti, I.; Oelmüller, R.; Lou, B. Piriformospora indica confers drought tolerance in Chinese cabbage leaves by stimulating antioxidant enzymes, the expression of drought-related genes and the plastid-localized CAS protein. J. Plant Physiol. 2010, 167, 1009-1017. [CrossRef]

113. Pinzone, P.; Potts, D.; Pettibone, G.; Warren II, R. Do novel weapons that degrade mycorrhizal mutualisms promote species invasion? Plant Ecol. 2018, 219, 539-548. [CrossRef]

114. Eid, K.E.; Abbas, M.H.H.; Mekawi, E.M.; ElNagar, M.M.; Abdelhafez, A.A.; Amin, B.H.; Mohamed, I.; Ali, M.M. Arbuscular mycorrhiza and environmentally biochemicals enhance the nutritional status of Helianthus tuberosus and induce its resistance against Sclerotium rolfsii. Ecotoxicol. Environ. Saf. 2019, 186, 109783. [CrossRef]

115. Pringle, A.; Bever, J.D.; Gardes, M.; Parrent, J.L.; Rillig, M.C.; Klironomos, J.N. Mycorrhizal Symbioses and Plant Invasions. Annu. Rev. Ecol. Evol. Syst. 2009, 40, 699-715. [CrossRef]

116. Phillips, M.L.; Weber, S.E.; Andrews, L.V.; Aronson, E.L.; Allen, M.F.; Allen, E.B. Fungal community assembly in soils and roots under plant invasion and nitrogen deposition. Fungal Ecol. 2019, 40, 107-117. [CrossRef]

117. Gemeda, W.S. Effects of Prosopis juliflora on Soil Microbial and Other Pathogenic Activities: A Review Paper. CPQ Microbiol. 2019, $3,1-8$.

118. Soliman, A.S.; Shanan, N.T.; Massoud, O.N.; Swelim, D.M. Improving salinity tolerance of Acacia saligna (Labill.) plant by arbuscular mycorrhizal fungi and Rhizobium inoculation. Afr. J. Biotechnol. 2012, 11, 1259-1266.

119. Badalamenti, E.; Ciolfi, M.; Lauteri, M.; Quatrini, P.; Mantia, T. Effects of Arbuscular Mycorrhizal Fungi on the Vegetative Vigor of Ailanthus altissima (Mill.) Swingle Seedlings under Sustained Pot Limitation. Forests 2018, 9, 409. [CrossRef]

120. Silva, I.R.d.; Mello, C.M.A.d.; Ferreira Neto, R.A.; Silva, D.K.A.d.; Melo, A.L.d.; Oehl, F.; Maia, L.C. Diversity of arbuscular mycorrhizal fungi along an environmental gradient in the Brazilian semiarid. Agric. Ecosyst. Environ. Appl. 2014, 84, 166-175. [CrossRef]

121. Menezes, K.M.S.; Silva, D.K.A.; Queiroz, M.A.A.; Félix, W.P.; Yano-Melo, A.M. Arbuscular mycorrhizal fungal communities in buffelgrass pasture under intercropping and shading systems in Brazilian semiarid conditions. Agric. Ecosyst. Environ. 2016, 230, 55-67. [CrossRef]

122. Belay, Z.; Vestberg, M.; Assefa, F. Diversity and abundance of arbuscular mycorrhizal fungi associated with acacia trees from different land use systems in Ethiopia. Afr. J. Microbiol. Res. 2013, 7, 5503-5515. [CrossRef] 
123. El-Khateeb, M.A.; El-Leithy, A.S.; Aljemaa, B.A. Effect of mycorrhizal fungi inoculation and humic acid on vegetative growth and chemical composition of Acacia saligna Labill. seedlings under different irrigation intervals. J. Hortic. Sci. Ornam. Plants 2011, 3, 283-289.

124. Mortimer, P.; Le Roux, M.; Pérez-Fernández, M.; Benedito, V.; Kleinert, A.; Xu, J.; Valentine, A. The dual symbiosis between arbuscular mycorrhiza and nitrogen fixing bacteria benefits the growth and nutrition of the woody invasive legume Acacia cyclops under nutrient limiting conditions. Plant Soil 2013, 366, 229-241. [CrossRef]

125. Duponnois, R.; Plenchette, C.; Bâ, A.M. Growth stimulation of seventeen fallow leguminous plants inoculated with Glomus aggregatum in Senegal. Eur. J. Soil Biol. 2001, 37, 181-186. [CrossRef]

126. Mahdhi, M.; Tounekti, T.; Khemira, H. Invasive Character of Prosopis juliflora Facilitated by its Allelopathy and a Wide Mutualistic Interaction with Soil Microorganisms. J. Biol. Sci. 2018, 18, 115-123. [CrossRef]

127. Shah, M.; Reshi, Z.; Khasa, D. Arbuscular Mycorrhizas: Drivers or Passengers of Alien Plant Invasion. Bot. Rev. 2009, 75, 397-417. [CrossRef]

128. Vitousek, P.M.; Menge, D.N.L.; Reed, S.C.; Cleveland, C.C. Biological nitrogen fixation: Rates, patterns and ecological controls in terrestrial ecosystems. Philos. Trans. Biol. Sci. 2013, 368, 20130119. [CrossRef]

129. Otieno, J.O.; Odee, D.W.; Omondi, S.F.; Oduor, C.; Kiplagat, O. Isolation and characterization of nitrogen fixing bacteria that nodulate alien invasive plant species Prosopis juliflora (Swart) DC. in Marigat, Kenya. Trop. Plant Res. 2017, 4, 183-191. [CrossRef]

130. Pathak, R.; Singh, S.K.; Gehlot, P. Diversity, Nitrogen fixation, and Biotechnology of Rhizobia from Arid Zone Plants. In Rhizobium Biology and Biotechnology; Springer International Publishing: Cham, Switzerland, 2017; pp. 61-81.

131. Zahran, H.H. Legume-Microbe Interactions under Stressed Environments. In Microbes for Legume Improvement; Springer International Publishing: Cham, Switzerland, 2017; pp. 301-339.

132. Benata, H.; Mohammed, O.; Noureddine, B.; Abdelbasset, B.; Abdelmoumen, H.; Muresu, R.; Squartini, A.; Idrissi, M.M.E. Diversity of bacteria that nodulate Prosopis juliflora in the eastern area of Morocco. Syst. Appl. Microbiol. 2008, 31, 378-386. [CrossRef] [PubMed]

133. Sharma, S.; Malage, A.; Sibi, G. Quantitative analysis of biological nitrogen fixation in various models of legumes and the factors influencing the process: A review. J. Crit. Rev. 2019, 24-28. [CrossRef]

134. Rashid, M.I.; Mujawar, L.H.; Shahzad, T.; Almeelbi, T.; Ismail, I.M.I.; Oves, M. Bacteria and fungi can contribute to nutrients bioavailability and aggregate formation in degraded soils. Microbiol. Res. 2016, 183, 26-41. [CrossRef]

135. Khan, A.G. Role of soil microbes in the rhizospheres of plants growing on trace metal contaminated soils in phytoremediation. $J$. Trace Elem. Med. Boil. 2005, 18, 355-364. [CrossRef]

136. Maestre, F.T.; Delgado-Baquerizo, M.; Jeffries, T.C.; Eldridge, D.J.; Ochoa, V.; Gozalo, B.; Quero, J.L.; García-Gómez, M.; Gallardo, A.; Ulrich, W.; et al. Increasing aridity reduces soil microbial diversity and abundance in global drylands. Proc. Natl. Acad. Sci. USA 2015, 112, 15684-15689. [CrossRef] [PubMed]

137. Elsheikh, E.A.E.; Wood, M. Response of chickpea and soybean rhizobia to salt: Osmotic and specific ion effects of salts. Soil Biol. Biochem. 1989, 21, 889-895. [CrossRef]

138. Elsheikh, E.A.E.; Wood, M. Rhizobia and bradyrhizobia under salt stress: Possible role of trehalose in osmoregulation. Lett. Appl. Microbiol. 1990, 10, 127-129. [CrossRef]

139. Elsheikh, E.A.E.; Wood, M. Nodulation and N 2 fixation by soybean inoculated with salt-tolerant rhizobia or salt-sensitive bradyrhizobia in saline soil. Soil Boil. Biochem. 1995, 27, 657-661. [CrossRef]

140. Egamberdieva, D.; Wirth, S.; Bellingrath-Kimura, S.D.; Mishra, J.; Arora, N.K. Salt-Tolerant Plant Growth Promoting Rhizobacteria for Enhancing Crop Productivity of Saline Soils. Front. Microbiol. 2019, 10, 2791. [CrossRef]

141. Dhull, S.; HS, S.; Kakar, R.; Gera, R. Selection of temperature stress tolerance of Rhizobium isolated from root nodules of clusterbean [Cyamopsis tetragonoloba (L.) Taub.] growing in arid and semi-arid regions of Haryana, India. Ann. Biol. 2018, $34,24-27$.

142. Marinkovic, J.; Bjelic, D.; AorAevic, V.; Balesevic-Tubic, S.; Josic, D.; Vucelic-Radovic, B. Performance of different Bradyrhizobium strains in root nodule symbiosis under drought stress. Acta Physiol. Plant 2019, 41, 37. [CrossRef]

143. Elsheikh, E.A.E. Effects of salt on rhizobia and bradyrhizobia: A review. Ann. Appl. Biol. 1998, 132, 507-524. [CrossRef]

144. Mahdhi, M.; Tounekti, T.; Khemira, H. Status and need of research on rhizobia and arbuscular mycorrhizal Fungi associated with leguminous plants in Saudi Arabia. Am. J. Curr. Microbiol. 2017, 5, 1-8.

145. Galaviz, C.; Lopez, B.R.; de-Bashan, L.E.; Hirsch, A.M.; Maymon, M.; Bashan, Y. Root growth improvement of mesquite seedlings and bacterial rhizosphere and soil community changes are induced by inoculation with plant growth-promoting bacteria and promote restoration of eroded desert soil. Land Degrad. Dev. 2018, 29, 1453-1466. [CrossRef]

146. Ramana, C.V.; Parag, B.; Girija, K.R.; Ram, B.R.; Ramana, V.V.; Sasikala, C. Rhizobium subbaraonis sp. nov., an endolithic bacterium isolated from beach sand. Int. J. Syst. Evol. Microbiol. 2013, 63, 581-585. [CrossRef] [PubMed]

147. Chen, W.X.; Wang, E.T.; Wang, S.Y.; Li, Y.B.; Chen, X.Q.; Li, J. Characteristics of Rhizobium tianshanense sp. nov., a Moderately and Slowly Growing Root Nodule Bacterium Isolated from an Arid Saline Environment in Xinjiang, People's Republic of China. Int. J. Syst. Bacteriol. 1995, 45, 153-159. [CrossRef]

148. Dupuy, N.; Willems, A.; Pot, B.; Dewettinck, D.; Vandenbruaene, I.; Maestrojuan, G.; Dreyfus, B.; Kersters, K.; Collins, M.D.; Gillis, M. Phenotypic and Genotypic Characterization of Bradyrhizobia Nodulating the Leguminous Tree Acacia albida. Int. J. Syst. Bacteriol. 1994, 44, 461-473. [CrossRef] 
149. Dupuy, N.C.; Dreyfus, B.L. Bradyrhizobium Populations Occur in Deep Soil under the Leguminous Tree Acacia albida. Appl. Environ. Microbiol. 1992, 58, 2415-2419. [CrossRef]

150. Marsudi, N.D.S.; Glenn, A.R.; Dilworth, M.J. Identification and characterization of fast- and slow-growing root nodule bacteria from South-Western Australian soils able to nodulate Acacia saligna. Soil Boil. Biochem. 1999, 31, 1229-1238. [CrossRef]

151. Birnbaum, C.; Bissett, A.; Thrall, P.H.; Leishman, M.R. Nitrogen-fixing bacterial communities in invasive legume nodules and associated soils are similar across introduced and native range populations in Australia. J. Biogeogr. 2016, 43, 1631-1644. [CrossRef]

152. Alshaharani, T.S.; Shetta, N.D. Phenotypic and biochemical characterization of root nodule bacteria naturally associated with woody tree legumes in Saudi Arabia. J. Environ. Biol. 2015, 36, 363-370. [PubMed]

153. Sharma, S.; Rao, N.; Gokhale, T.; Ismail, S. Isolation and characterization of salt-tolerant rhizobia native to the desertsoils of United Arab Emirates. Emir. J. Food Agric. 2013, 25, 102. [CrossRef]

154. Fterich, A.; Mahdhi, M.; Caviedes, M.; Pajuelo, E.; Rivas, R.; Rodriguez-Llorente, I.; Mars, M. Characterization of root-nodulating bacteria associated to Prosopis farcta growing in the arid regions of Tunisia. Arch. Microbiol. 2011, 193, 385-397. [CrossRef]

155. Helene, L.C.F.; Delamuta, J.R.M.; Ribeiro, R.A.; Ormeño-Orrillo, E.; Rogel, M.A.; Martínez-Romero, E.; Hungria, M. Bradyrhizobium viridifuturi sp. nov., encompassing nitrogen-fixing symbionts of legumes used for green manure and environmental services. Int. J. Syst. Evol. Microbil. 2015, 65, 4441-4448. [CrossRef]

156. Shetta, N.D.; Al-Shaharani, T.S.; Abdel-Aal, M. Identification and characterization of Rhizobium associated with woody legume trees grown under Saudi Arabia condition. Am. Eurasian J. Agric. Environ. Sci. 2011, 10, 410-418.

157. Boukhatem, Z.F.; Domergue, O.; Bekki, A.; Merabet, C.; Sekkour, S.; Bouazza, F.; Duponnois, R.; de Lajudie, P.; Galiana, A. Symbiotic characterization and diversity of rhizobia associated with native and introduced acacias in arid and semi-arid regions in Algeria. FEMS Microbiol. Ecol. 2012, 80, 534-547. [CrossRef]

158. Ceccon, E.; Almazo-Rogel, A.; Martínez-Romero, E.; Toledo, I. The effect of inoculation of an indigenous bacteria on the early growth of Acacia farnesiana in a degraded area. Cerne 2012, 18, 49-57. [CrossRef]

159. Lebrazi, S.; Chraibi, M.; Fadil, M.; Barkai, H.; Fikri-Benbrahim, K. Phenotypic, Genotypic and Symbiotic Characterization of Rhizobial Isolates Nodulating Acacia sp. in Morocco. J. Pure Appl. Microbiol. 2018, 12, 249-263. [CrossRef]

160. Swelim, D.M.; Ali, M.A.; El-Khatib, E.I. Some tree-legume-rhizobia are meagerly arising in Egyptian soil. Aust. J. Basic Appl. Sci. 2010, 4, 1297-1304.

161. Stock, W.D.; Wienand, K.T.; Baker, A.C. Impacts of invading $\mathrm{N}_{2}$-fixing Acacia species on patterns of nutrient cycling in two Cape ecosystems: Evidence from soil incubation studies and 15N natural abundance values. Oecologia 1995, 101, 375-382. [CrossRef] [PubMed]

162. Graham, P.H. Stress tolerance in Rhizobium and Bradyrhizobium, and nodulation under adverse soil conditions. Canad. J. Microbiol. 1992, 38, 475-484. [CrossRef]

163. Liu, Y.; Wu, L.; Baddeley, J.A.; Watson, C.A. Models of biological nitrogen fixation of legumes. Agron. Sustain. Dev. 2011, 31, 155-172. [CrossRef]

164. Polley, H.W.; Johnson, H.B.; Mayeux, H.S. Leaf physiology, production, water use, and nitrogen dynamics of the grassland invader Acacia smallii at elevated $\mathrm{CO}_{2}$ concentrations. Tree Physiol. 1997, 17, 89-96. [CrossRef]

165. Brockwell, J.; Searle, S.D.; Jeavons, A.C.; Waayers, M. Nitrogen Fixation in Acacias: An Untapped Resource for Sustainable Plantations, Farm Forestry and Land Reclamation. 2005. Available online: https://ideas.repec.org/b/ags/aciarm/114065.html (accessed on 11 November 2021).

166. Mahmud, K.; Makaju, S.; Ibrahim, R.; Missaoui, A. Current Progress in Nitrogen Fixing Plants and Microbiome Research. Plants 2020, 9, 97. [CrossRef]

167. Felker, P.; Clark, P.R. Nitrogen fixation (acetylene reduction) and cross inoculation in 12 Prosopis (mesquite) species. Plant Soil. 1980, 57, 177-186. [CrossRef]

168. Hughes, R.F.; Denslow, J.S. Invasion by a N2-fixing tree alters function and structure in wet lowland forests of Hawaii. Ecol. Appl. 2005, 15, 1615-1628. [CrossRef]

169. Goldstein, C.L.; Williard, K.W.J.; Schoonover, J.E.; Baer, S.G.; Groninger, J.W.; Snyder, J.M. Soil and Groundwater Nitrogen Response to Invasion by an Exotic Nitrogen-Fixing Shrub. J. Environ. Qual. 2010, 39, 1077-1084. [CrossRef] [PubMed]

170. Mahdhi, M.; Tounekti, T.; Khemira, H. Occurrence of arbuscular mycorrhizal fungi and nodules in the roots of twelve legume species in South-Western Saudi Arabia. Acta Sci. Pol.-Hortoru. Cultus. 2018, 17, 53-60. [CrossRef]

171. Rodríguez-Echeverría, S.; Crisóstomo, J.; Nabais, C.; Freitas, H. Belowground mutualists and the invasive ability of Acacia longifolia in coastal dunes of Portugal. Biol. Invasions 2009, 11, 651-661. [CrossRef]

172. Ndoye, F.; Kane, A.; Diedhiou, A.G.; Bakhoum, N.; Fall, D.; Sadio, O.; Sy, M.O.; Noba, K.; Diouf, D. Effects of dual inoculation with arbuscular mycorrhizal fungi and rhizobia on Acacia senegal (L.) Willd. seedling growth and soil enzyme activities in Senegal. Int. J. Biosci. 2015, 6, 36-48.

173. Mangan, S.A.; Bever, J.D.; Schnitzer, S.A.; Mack, K.M.L.; Valencia, M.C.; Sanchez, E.I.; Herre, E.A. Negative plant-soil feedback predicts tree-species relative abundance in a tropical forest. Nature 2010, 466, 752-755. [CrossRef]

174. Maron, J.L.; Klironomos, J.; Waller, L.; Callaway, R.M.; Austin, A. Invasive plants escape from suppressive soil biota at regional scales. J. Ecol. 2014, 102, 19-27. [CrossRef] 
175. Lorenzo, P.; Palomera-Pérez, A.; Reigosa, M.; González, L. Allelopathic interference of invasive Acacia dealbata Link on the physiological parameters of native understory species. Plant Ecol. 2011, 212, 403-412. [CrossRef]

176. Lorenzo, P.; Pereira, C.S.; Rodríguez-Echeverría, S. Differential impact on soil microbes of allelopathic compounds released by the invasive Acacia dealbata Link. Soil Boil. Biochem. 2013, 57, 156-163. [CrossRef]

177. Motard, E.; Muratet, A.; Clair-Maczulajtys, D.; Machon, N. Does the invasive species Ailanthus altissima threaten floristic diversity of temperate peri-urban forests? Comptes Rendus Biol. 2011, 334, 872-879. [CrossRef]

178. Jarchow, M.E.; Cook, B.J. Allelopathy as a Mechanism for the Invasion of Typha angustifolia. Plant Ecol. 2009, $204,113-124$. [CrossRef]

179. Singh, M.; Kumar, J.; Singh, S.; Singh, V.P.; Prasad, S.M. Roles of osmoprotectants in improving salinity and drought tolerance in plants: A review. Rev. Environ. Sci. Biotechnol. 2015, 14, 407-426. [CrossRef]

180. Shehu, Z.; Lamayi, D.W.; Sabo, M.A.; Shafiu, M.M. Synthesis, Characterization and Antibacterial Activity of Kaolin/Gum Arabic Nanocomposite on Escherichia Coli and Pseudomonas Aeruginosa. Res. J. Nanosci. Eng. 2018, 2, 23-29.

181. Padil, V.V.T.; Černík, M. Green synthesis of copper oxide nanoparticles using gum karaya as a biotemplate and their antibacterial application. Int. J. Nanomed. 2013, 8, 889-898. [CrossRef]

182. Saleh, I.; Abu-Dieyeh, M.H. Novel Prosopis juliflora leaf ethanolic extract as natural antimicrobial agent against food spoiling microorganisms. Sci. Rep. 2021, 11, 7871. [CrossRef]

183. Badri, A.M.; Garbi, M.I.; Kabbashi, A.S.; Saleh, M.S.; Yousof, Y.S.; Mohammed, S.F.; Ibrahim, I.T.; Magzoub, A.A. In vitro anti-bacterial activity of Prosopis juliflora leafs extract against pathogenic bacteria. Adv. Med. Plant Res. 2017, 5, 1-4. [CrossRef]

184. Alkaabi, D.; Gasmelbari, M.; Abumukhaimar, N.H.; A./Futuh Shandal, I. Antimicrobial activity of United Arab Emirates indigenous medicinal plants Prosopis cineraria, Prosopis juliflora and Acacia tortilis. Hamdan Med. J. 2020, 13, 110-114. [CrossRef]

185. Mazinani, Z.; Zamani, M.; Sardari, S. Isolation and identification of phyllospheric bacteria possessing antimicrobial activity from Astragalus obtusifolius, Prosopis juliflora, Xanthium strumarium and Hippocrepis unisiliqousa. Avicenna J. Med. Biotechnol. $2017,9,31$.

186. Mdee, L.K.; Masoko, P.; Eloff, J.N. The activity of extracts of seven common invasive plant species on fungal phytopathogens. $S$. Afr. J. Bot. 2009, 75, 375-379. [CrossRef]

187. Garg, V.K.; Singh, B. Macronutrient dynamics and use efficiency in three species of short rotation forestry developed on sodic soils in North India. J. Trop. For. Sci. 2003, 15, 289-302.

188. Kaur, R.; Callaway, R.M. Inderjit Soils and the conditional allelopathic effects of a tropical invader. Soil Boil. Biochem. 2014, 78, 316-325. [CrossRef]

189. Abd El Gawad, A.M.; El-Amier, Y.A. Allelopathy and Potential Impact of Invasive Acacia saligna (Labill.) Wendl. on Plant Diversity in the Nile Delta Coast of Egypt. Int. J. Environ. Res. 2015, 9, 923-932.

190. Aslam, M.M.; Jamil, M.; Malook, I.; Khatoon, A.; Rehman, A.; Khan, P.; Shakir, U.K.S.; Irfan, I.; Ullah, F.; Bashar, K.U.; et al. Phytotoxic effects of Calotropis procera, Tamarix aphylla and Peganum harmala on plant growth of wheat and mustard. Pak. J. Agric. Res. 2016, 29.

191. Luo, Y.; Du, Z.; Yan, Z.; Zhao, X.; Li, Y.; Jiang, H.; Yang, Y.; Li, M. Artemisia halodendron Litters Have Strong Negative Allelopathic Effects on Earlier Successional Plants in a Semi-Arid Sandy Dune Region in China. Front. Plant Sci. 2020, 11, 961. [CrossRef]

192. Cantor, A.; Hale, A.; Aaron, J.; Traw, M.; Kalisz, S. Low allelochemical concentrations detected in garlic mustard-invaded forest soils inhibit fungal growth and AMF spore germination. Biol. Invasions 2011, 13, 3015-3025. [CrossRef]

193. Yuan, G.; Zhang, P.; Shao, M.; Luo, Y.; Zhu, X. Energy and water exchanges over a riparian Tamarix spp. stand in the lower Tarim River basin under a hyper-arid climate. Agric. For. Meteorol. 2014, 194, 144-154. [CrossRef]

194. Ma, R.J.; Wang, N.L.; Zhu, H.; Guo, S.J.; Chen, D.S. Isolation and identification of allelochemicals from invasive plant Ipomoea cairica. Allelopath. J. 2009, 24.

195. Thiébaut, G.; Tarayre, M.; Rodríguez-Pérez, H. Allelopathic Effects of Native versus Invasive Plants on One Major Invader. Front. Plant Sci. 2019, 10, 854. [CrossRef]

196. Pearse, I.; Bastow, J.; Tsang, A. Radish introduction affects soil biota and has a positive impact on the growth of a native Plant. Oecologia 2014, 174, 471-478. [CrossRef]

197. Portales-Reyes, C.; Van Doornik, T.; Schultheis, E.H.; Suwa, T. A novel impact of a novel weapon: Allelochemicals in Alliaria petiolata disrupt the legume-rhizobia mutualism. Biol. Invasions 2015, 17, 2779-2791. [CrossRef]

198. Alford, É.R.; Vivanco, J.M.; Paschke, M.W. The Effects of Flavonoid Allelochemicals from Knapweeds on Legume-Rhizobia Candidates for Restoration. Restor. Ecol. 2009, 17, 506-514. [CrossRef]

199. Aschehoug, E.; Callaway, R.; Newcombe, G.; Tharayil, N.; Chen, S. Fungal endophyte increases the allelopathic effects of an invasive forb. Oecologia 2014, 175, 285-291. [CrossRef]

200. Latif, S.; Chiapusio, G.; Weston, L.A. Allelopathy and the Role of Allelochemicals in Plant Defence. In How Plants Communicate with Their Biotic Environment; Academic Press, INC, 2017; Volume 82, pp. 19-54. Available online: https:/ / www.sciencedirect. com/science/article/abs/pii/S0065229616301203 (accessed on 11 November 2021).

201. Hierro, J.L.; Callaway, R.M. Allelopathy and exotic plant invasion. Plant Soil. 2003, 256, 29-39. [CrossRef]

202. Meng, P.; Pei, H.; Hu, W.; Liu, Z.; Li, X.; Xu, H. Allelopathic effects of Ailanthus altissima extracts on Microcystis aeruginosa growth, physiological changes and microcystins release. Chemosphere 2015, 141, 219-226. [CrossRef] [PubMed]

203. Zhang, X.; Lu, G.; Long, W.; Zou, X.; Li, F.; Nishio, T. Recent progress in drought and salt tolerance studies in Brassica crops. Breed. Sci. 2014, 64, 60-73. [CrossRef] [PubMed] 
204. McLeod, M.L.; Cleveland, C.C.; Lekberg, Y.; Maron, J.L.; Philippot, L.; Bru, D.; Callaway, R.M.; Aerts, R. Exotic invasive plants increase productivity, abundance of ammonia-oxidizing bacteria and nitrogen availability in intermountain grasslands. J. Ecol. 2016, 104, 994-1002. [CrossRef]

205. de Souza, T.A.F.; Rodriguez-Echeverría, S.; Andrade, L.A.d.; Freitas, H. Could biological invasion by Cryptostegia madagascariensis alter the composition of the arbuscular mycorrhizal fungal community in semi-arid Brazil? Acta Bot. Bras. 2016, 30, 93-101. [CrossRef]

206. Rodriguez, P.A.; Rothballer, M.; Chowdhury, S.P.; Nussbaumer, T.; Gutjahr, C.; Falter-Braun, P. Systems Biology of PlantMicrobiome Interactions. Mol. Plant 2019, 12, 804-821. [CrossRef]

207. Zubek, S.; Majewska, M.; Błaszkowski, J.; Stefanowicz, A.; Nobis, M.; Kapusta, P. Invasive plants affect arbuscular mycorrhizal fungi abundance and species richness as well as the performance of native plants grown in invaded soils. Biol. Fertil. Soils 2016, 52, 879-893. [CrossRef]

208. Inderjit; van der Putten, W.H. Impacts of soil microbial communities on exotic plant invasions. Ecol. Evol. 2010, 25, 512-519. [CrossRef] [PubMed]

209. Rillig, M.C. Arbuscular mycorrhizae and terrestrial ecosystem processes. Ecol. Lett. 2004, 7, 740-754. [CrossRef]

210. Santos, M.S.; Nogueira, M.A.; Hungria, M. Microbial inoculants: Reviewing the past, discussing the present and previewing an outstanding future for the use of beneficial bacteria in agriculture. AMB Express 2019, 9, 205-222. [CrossRef] [PubMed]

211. Crisóstomo, J.A.; Rodríguez-Echeverría, S.; Freitas, H. Co-introduction of exotic rhizobia to the rhizosphere of the invasive legume Acacia saligna, an intercontinental study. Appl. Soil Ecol. 2013, 64, 118-126. [CrossRef]

212. Trabelsi, D.; Mhamdi, R. Microbial Inoculants and Their Impact on Soil Microbial Communities: A Review. Biomed. Res. Int. 2013, 2013, 863240. [CrossRef] [PubMed] 